Florida International University FIU Digital Commons

$4-15-2015$

\title{
Role of the Audit Committee Chair in the Financial Reporting Process
}

Izhar Haq

haqi@fiu.edu

DOI: $10.25148 /$ etd.FIDC000101

Follow this and additional works at: https://digitalcommons.fiu.edu/etd

Part of the Accounting Commons

\section{Recommended Citation}

Haq, Izhar, "Role of the Audit Committee Chair in the Financial Reporting Process" (2015). FIU Electronic Theses and Dissertations. 2212.

https://digitalcommons.fiu.edu/etd/2212

This work is brought to you for free and open access by the University Graduate School at FIU Digital Commons. It has been accepted for inclusion in FIU Electronic Theses and Dissertations by an authorized administrator of FIU Digital Commons. For more information, please contact dcc@fiu.edu. 


\section{FLORIDA INTERNATIONAL UNIVERSITY}

Miami, Florida

\section{ROLE OF THE AUDIT COMMITTEE CHAIR IN THE FINANCIAL REPORTING PROCESS}

A dissertation submitted in partial fulfillment of the requirement for the degree of DOCTOR OF PHILOSOPHY in BUSINESS ADMINISTRATION

by

Izhar Haq 
To: Acting Dean Jose M. Aldrich

College of Business Administration

This dissertation, written by Izhar Haq, and entitled Role of the Audit Committee Chair in the Financial Reporting Process, having been approved in respect to style and intellectual content, is referred to you for judgment.

We have read this dissertation and recommend that it be approved.

Abhijit Barua

Suchismita Mishra

Dasaratha Rama, Co-Major Professor

Kannan Raghunandan, Co-Major Professor

Date of Defense: April 15, 2015

The dissertation of Izhar Haq is approved.

Acting Dean Jose M. Aldrich
College of Business Administration

Florida International University, 2015 
(C) Copyright 2015 by Izhar Haq

All rights reserved. 


\section{DEDICATION}

I dedicate my dissertation work in memory of my mother and father. They left the country of their birth to give a better life for their children. They were my inspiration to pursue my doctoral degree but were unable to see me attain it.

I also dedicate my dissertation to my wife Yvette for supporting my decision to purse a doctorate and being there for me throughout the doctoral program. Her words of encouragement and push for tenacity kept me going. My wife Yvette and my son Alexander form the basis of my happiness. Their love and support has enabled me to complete my Ph.D. I owe my every achievement to both of them. 


\section{ACKNOWLEDGMENTS}

I am deeply indebted to my major professor Kannan Raghunandan for his fundamental role in my doctoral work. Dr. Raghunandan accepted me into the program and continued to provide me with every bit of assistance and expertise that I needed. His advice, patient supervision, and guidance were greatly appreciated. I have leaned a lot from him and without his help and support I could not have finished my dissertation successfully. It has been an honor and a privilege to have the opportunity to work with a preeminent scholar in Accounting such as Dr. Raghunandan.

I gratefully acknowledge the members of my Ph.D. committee for their time and valuable feedback on my dissertation. Their critical comments enabled me to notice the weaknesses of my dissertation and make the necessary improvements based on their feedback. I would particularly like to acknowledge Abhijit Barua for his generosity of time and expertise. He always made from his busy schedule to answer any questions that I had and his assistance in the abnormal accrual regressions was invaluable.

I would also like to thank Ruth Ann McEwen whose firm and kind-hearted efforts to ensure that I maintained my focus in completing my doctoral degree motivated me to work harder and do my best. 


\section{ABSTRACT OF THE DISSERTATION \\ ROLE OF THE AUDIT COMMITTEE CHAIR IN THE FINANCIAL REPORTING PROCESS}

by

Izhar Haq

Florida International University, 2015

Miami, Florida

\section{Professor Dasaratha Rama, Co-Major Professor \\ Professor Kannan Raghunandan, Co-Major Professor}

In my dissertation, I examine the role of the audit committee chair in the financial reporting process and test if the change in audit committee chair is associated with changes in audit fees, audit report lag, and audit quality. Motivation for this dissertation comes from the increased attention paid by legislators and regulators in recent years on the role of the audit committee in the financial reporting process. While prior studies have examined diverse issues related to the composition of the audit committee, no prior study has examined the role of the audit committee chair on the oversight of financial reporting, even though the chair of the committee has significant control over the functioning of the committee.

In the first essay of my dissertation, I show that audit fees are higher in firms that have a change in the audit committee chair. In the second essay, I examine the association between changes in the audit committee chair and audit report lag. In a changes regression, I find that the change in audit committee is associated with higher audit report lag. The third essay examines the association between changes in audit 
committee chair and two different measures of audit quality: restatements and abnormal accruals. There is no evidence in support of the argument that changes in audit committee chair is associated with higher quality financial reporting. Overall, the results suggest that the change in audit committee chair has an important impact on the financial reporting process of public companies. 


\section{TABLE OF CONTENTS}

CHAPTER

PAGE

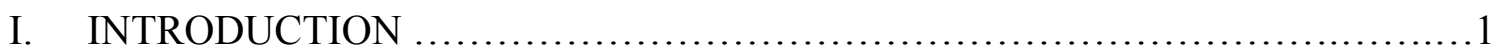

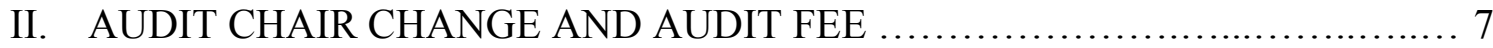

Motivation ..................................................................... 7

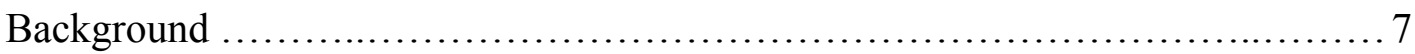

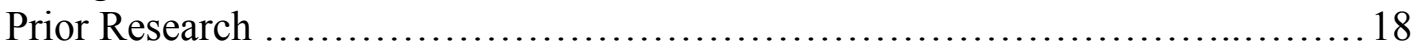

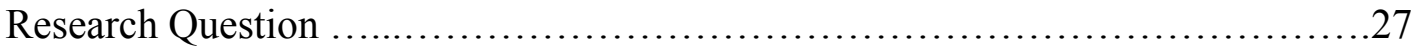

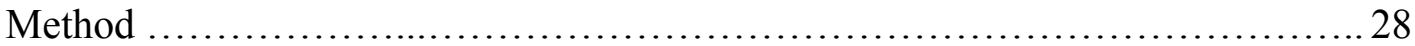

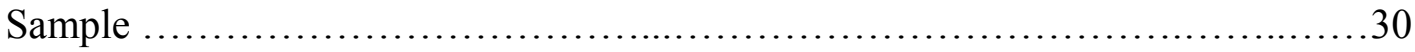

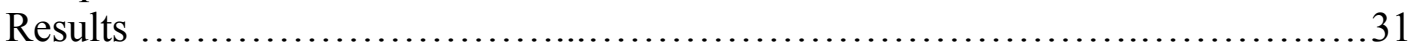

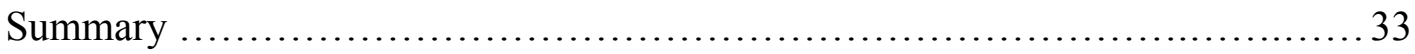

III. AUDIT CHAIR CHANGE AND AUDIT REPORT LAGS …..................... 34

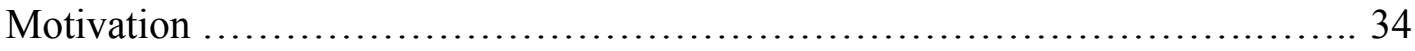

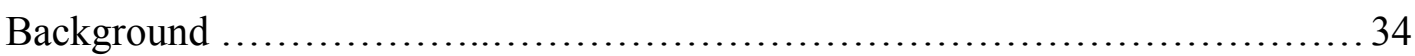

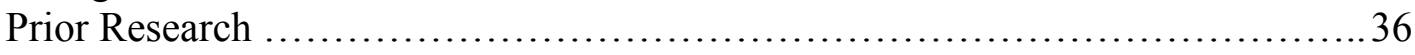

Research Question ........................................................... 45

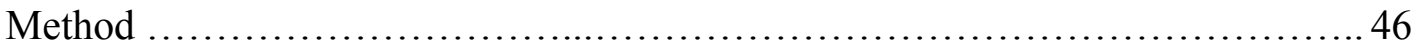

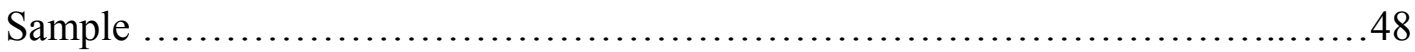

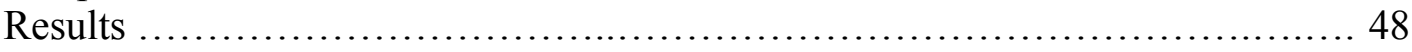

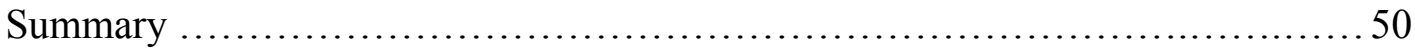

IV. AUDIT CHAIR CHANGE AND AUDIT QUALITY ...........................5 51

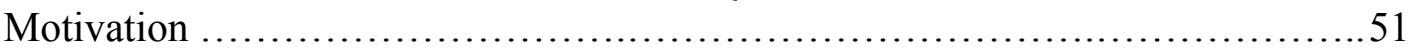

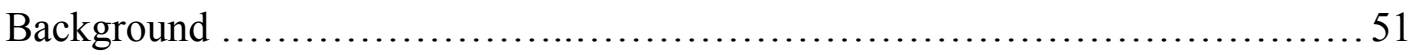

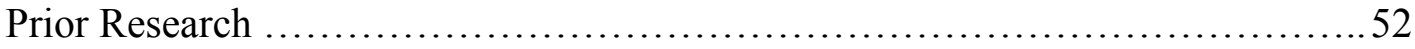

Research Question ...................................................... 57

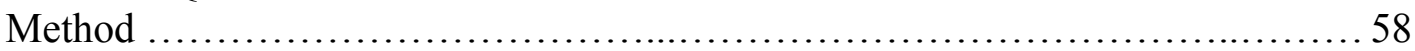

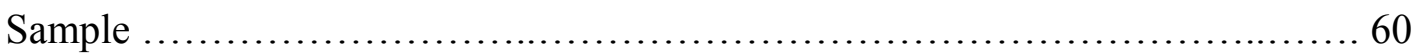

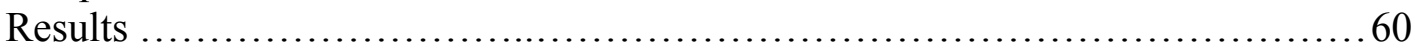

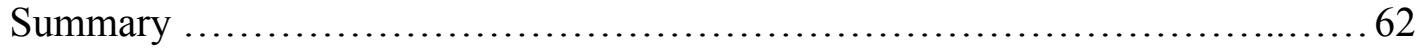

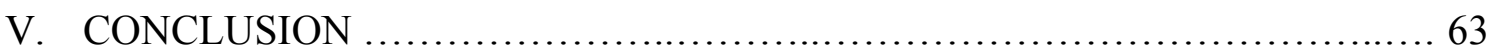

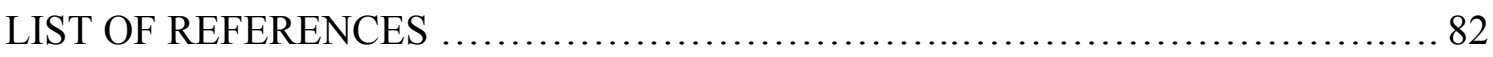

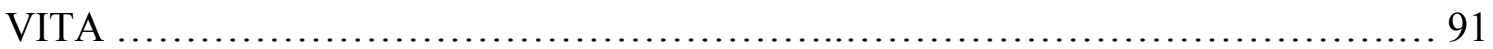




\section{LIST OF TABLES}

TABLE

PAGE

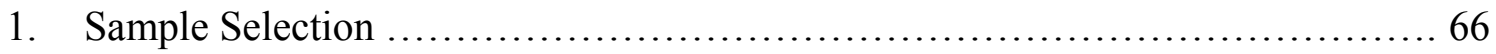

2. Descriptive Statistics for the Audit Fee Models ............................. 67

3. Regression Results for the Audit Fee Models ................................ 69

4. Descriptive Statistics for the Audit Report Lag Models ...................... 70

5. Regression Results for the Audit Report Lag Models ...................... 72

6. Descriptive Statistics for the Audit Report Lag Changes Model ..................73

7. Regression Results for the Audit Report Lag Changes Model ................... 75

8. Descriptive Statistics for the Restatements Models .......................... 76

9. Logistic Regression Results for the Restatement Models ........................77

10. Descriptive Statistics for Performance Matched Accruals Models ............. 78

11. Regression Results for Performance Matched Total Accruals Models ........... 80

12. Regression Results for Performance Matched Working Capital Accruals Models 81 


\section{INTRODUCTION}

In publicly traded companies the audit committee is responsible for the selection of the external audit firm, receipt of results from both internal and external audits, and the oversight of the financial reporting process including disagreements between management and the external auditors. Oversight of the financial reporting process is perhaps the most important function of the audit committee and has received significant attention in recent years from both media and regulatory bodies, primarily due to the spectacular failures (such as, Enron and WorldCom) that have taken place. The financial reporting process oversight can be quite complex as it entails not only the review of quarterly and annual financial statements, but also ensuring that accounting estimates and implementation of accounting principles are reasonable. This typically requires audit committees to discuss complex accounting issues and discussions with external auditors to address any disagreements by the external auditors on management's selection of accounting principles and accounting adjustments. Audit committees are also responsible for reviewing any fraud or illegal acts committed by management that was identified by external auditors as part of the financial audit.

Although the Securities and Exchange Commission (SEC) first encouraged the concept of the audit committee in 1940 as a result of the McKesson case, it was not until the 1970's that audit committees became common in U.S. corporations (AICPA, 1978). In 1972 the Securities and Exchange Commission issued Accounting Series Release No. 123 , in which it reiterated its interest in publicly traded companies establishing audit committees and that those committees should be composed of independent directors. In 
1977, at the urging of the Securities and Exchange Commission, the New York Stock Exchange adopted a listing requirement that all companies listed in the New York Stock Exchange establish a standing audit committee. In 1977, the board of directors of the American Institute of Certified Public Accountants (AICPA) also supported the establishment of audit committees and strongly urged members to support the idea. The AICPA also called on all the stock exchanges in the United States to adopt audit committee requirements similar to the New York Stock Exchange. In subsequent years, the SEC and General Accounting Office continued to push for the formation of effective audit committees.

While audit committees were becoming more common in publicly traded companies during the 1970s and 1980s, there were no established standards for the composition and responsibility of the committee. As a result of concerns raised by SEC Chair Arthur Levitt regarding the adequacy of oversight by audit committees, the Blue Ribbon Committee on Improving the Effectiveness of Corporate Audit Committees (which was composed of individuals from the New York Stock Exchange, NASDAQ, CPA firms, and public companies) was established in 1998 and in 1999 issued recommendations to improve the effectiveness of audit committees. In 1999, all the major exchanges adopted a number of Blue Ribbon Committee recommendations.

After the Enron and WorldCom scandals, Congress passed the Sarbanes-Oxley Act (SOX) in 2002. Section 301 of SOX requires the SEC to establish rules prohibiting the listing of companies that are not in compliance with standards established for audit committees. The standards included direct responsibility for the appointment, 
compensation, and oversight of the outside auditors. Also, under SOX each member of the audit committee of publicly traded companies must be independent.

Given that standardized best practices for audit committees has only been around for about a decade, it's not surprising that accounting research into audit committees does not go much further back than 1996. Audit committee effectiveness can be assessed along the following four dimensions: Composition, Authority, Resources, and Diligence (DeZoort et al.2002). Prior research has concentrated on composition and diligence because they are the features about which data are publicly available. Much of the prior research on audit committee composition had focused on issues such as independence and financial expertise of the audit committee members. More recent studies have started to examine other issues related to composition, such as tenure and "busy boarding" by audit committee members (Sharma and Iselin 2011; Barua et al.2010).

One issue that has not received any attention in prior research is the role of the audit committee chair. This is surprising, given the extensive focus on the role of the board of directors chair in governance research. Many prior studies have examined issues related to the role of the chair of the board of directors on the effectiveness of the monitoring by the board of directors. For example, many studies have examined issues related to the separation of the roles of the chair of the board of directors and the CEO. Carcello, Hermanson and Ye $(2011,32)$ note, in their extensive review of audit committees, that:

"Extant research frequently considers the role of the board chair in the governance process, including examining when it is optimal to combine the roles of board chair and CEO as well as examining the relative monitoring effectiveness of separating these positions versus combining them. However, very little research separately examines the role of the 
audit committee chair in facilitating effective audit committee performance (Bédard and Gendron 2010). Given the role of the audit committee chair in driving the agenda, the meeting packet, the conduct of the meeting, and interactions between meetings, this is an unfortunate oversight. We believe that examining the role of the audit committee chair, including the chair's behaviors, characteristics, and personality traits, in ensuring audit committee effectiveness is worthy of future study."

This dissertation extends prior research on audit committees by examining the role of the audit committee chair in the financial reporting process. I posit that audit committee chair turnover has a significant impact on the oversight of the financial statement process through the chair's involvement with management and external auditors during financial statement audits. The first part of the dissertation examines the impact of a change in audit committee chair on audit fees. The assumption is that a change in audit committee chair could lead to significant changes in audit fees. It is expected that a new audit committee chair may demand a more extensive audit, which would lead to higher audit fees. Prior research suggests that audit fees are influenced by characteristics of the audit committee because of the significant association between audit committee characteristics and the financial reporting process. Audit committees are tasked with oversight of the financial reporting process, which includes the selection and retention or replacement of the external auditors reviewing the financial statements. The audit committee is not only response for defining the scope of the audit but also to review and resolve disputes between management and the independent auditors. For example, Abbott et al.(2004) found that independence and activity had a significant negative association with the occurrence of restatements. Krishnan and Visvanathan (2008) found that accounting expertise enhances many aspects of the financial reporting process. A 
natural extension is to examine the effect of an audit committee chair change on audit fees.

The second part of the dissertation examines the impact of a change in audit committee chair on audit report lag. I posit that a change in chair leads to a more extensive audit, which will manifest itself in more work for the auditors resulting in a greater time lag for audit reports.

The third part of the dissertation follows naturally from the first two parts. If a change in the audit committee chair is associated with more extensive or better quality audits, then we should expect better quality financial reporting following the appointment of a new audit committee chair. I use two different measures of financial reporting quality (or, lack thereof): subsequent restatements of financial statements and abnormal accruals. This also follows naturally from prior research indicates that audit committee characteristics are associated with accruals quality (Klein 1999; Bedard et al. 2004) and restatements (Abbott et al. 2004).

I find that audit fees are higher in firms that have a change in the audit committee chair. The evidence related to the association between changes in the audit committee chair and audit report lag is mixed; I find evidence of such association in a changes model, but I do not find such association when using a levels model. I find that there is no association between the change in audit committee chair and subsequent restatements, while abnormal accruals (absolute value of both performance matched total accruals and performance matched working capital accruals) are positively associated with the change in audit committee chair. Thus, there is no evidence that the change in audit committee chair is associated with higher quality financial reporting. 
Overall, the results suggest that the change in audit committee chair has an important impact on the financial statement process of a company as it provides greater scrutiny of accounting decisions made by management. These results are consistent with prior research that corporate governance has a significant impact on the financial statement process and expands the body of knowledge on the role of the audit committee chair in the financial reporting oversight process of public companies. 


\section{AUDIT CHAIR CHANGE AND AUDIT FEE}

Motivation

Even though the importance of audit committees for publicly traded companies was widely accepted by the end of the 1970's, prior research has primarily focused on composition and diligence of the audit committee. There is no published research on the role of the audit committee chair in the financial reporting process. The important role played by the audit committee chairs was noted by Cacello, Hermanson, and Ye (2011).

Prior research suggests that audit fees are influenced by audit committee characteristics because of the significant role played by the audit committee in the financial reporting process. Given the significant role of the audit committee chair in setting the agenda of the committee and in the overall functioning of the audit committee, it is interesting to examine if audit fees are associated with changes in the audit committee chair.

The first part of the dissertation investigates the association between the audit committee chair change and audit fees. This part of the dissertation will add to the body of research on the association between audit committees and audit fees by determining the significance of the role played by the audit committee chair.

\section{Background}

Audit committees play an important role in ensuring high quality financial reporting. This is because the primary responsibilities of the audit committee include providing oversight over the financial reporting process. As part of its duties, this 
requires that the audit committee interact extensively with management, as well as both internal and external auditors.

Recognizing the importance of audit committees, the SEC (1999a) noted:

"Audit committees oversee and monitor management and the independent auditors in the financial reporting process, and thereby play a critical role in assuring the credibility of financial reporting. Audit committees can facilitate communications between a company's board of directors, its management, and its internal and independent auditors on significant accounting issues and policies. They can provide a forum separate from management in which auditors can candidly discuss any concerns. By effectively carrying out their many functions and responsibilities, audit committees help to enhance the reliability and credibility of financial reports."

The SEC also noted that it had, since at least the 1940s, encouraged the voluntary formation of effective audit committees. Specifically, the SEC (1999a) noted:

"Since the early 1940s, the Commission, along with the auditing and corporate communities, has had a continuing interest in promoting effective and independent audit committees. It was, in large measure, with the Commission's encouragement, for instance, that the self-regulatory organizations first adopted audit committee requirements in the 1970s. In 1974 and 1978, the Commission adopted rules requiring certain disclosures about audit committees. In 1980, the Commission issued a staff report on corporate accountability that addresses some of the issues underlying today's proposals. Former SEC Commissioner James Treadway led the National Commission on Fraudulent Financial Reporting that issued recommendations on corporate audit committees in 1987."

Yet, even during the 1980s, many public companies did not have an audit committee made up of independent directors. Pincus et al. (1989) find that NASDAQ listed public companies that voluntarily formed audit committees were larger, had higher proportion of outside directors and lower managerial ownership, than companies that did not have such audit committees. The results of Pincus et al. (1989) suggest that higher the agency costs, the more incentive a company has to form an audit committee. 
Early research supports the conjecture that the presence of an audit committee is associated with better financial reporting quality. McMullen (1996) formally tests the conjecture that the presence of an audit committee is associated with financial reporting quality. She measures (the lack of) high quality financial reporting by the incidence of errors, irregularities and illegal acts, shareholder litigation alleging fraudulent financial reporting, corrections of reported quarterly earnings, SEC enforcement action, and auditor turnover involving a disagreement with the client as proxies to measure financial reporting quality. McMullen (1996) finds that the presence of an audit committee is associated with reduced likelihood of shareholder lawsuits, restatements, enforcement actions and auditor turnover following disagreement between auditor and client.

While the formation of an audit committee is the first step, having solely independent directors on the committee is the second step. The Treadway Commission, referred to in the SEC (1999a) cite above, recommended that the SEC require public companies to have audit committees consisting only of independent directors. However, the SEC did not mandate such a requirement and, while many SEC registrants had audit committees comprising of only independent directors, there were numerous public companies that either did not have audit committees or had audit committees that did not have solely independent directors.

In 1998, SEC Chairman Arthur Levitt, in a speech entitled "The Numbers Game", discussed the role of audit committees in ensuring high quality financial reporting. His speech led to the formation of two private sector task forces about the formation and functioning of effective audit committees. The Report of the Blue Ribbon Committee on Improving the Effectiveness of Corporate Audit Committees (BRC 1999) and the National 
Association of Corporate Directors' Report of the NACD Blue Ribbon Commission on

Audit Committees (NACD 2000) included recommendations to improve audit committee effectiveness.

In addition to prodding the stock exchanges and public companies through speeches, the SEC also acted to strengthen the composition and functioning of audit committees. The SEC (1999b) adopted a rule "to improve disclosure relating to the functioning of corporate audit committees." Specifically, the SEC's (1999b) new rules require that:

- companies include reports of their audit committees in their proxy statements; in the report, the audit committee must state whether the audit committee has: (i) reviewed and discussed the audited financial statements with management; (ii) discussed with the independent auditors the matters required to be discussed by Statement on Auditing Standards No. 61, as may be modified or supplemented; and (iii) received from the auditors disclosures regarding the auditors' independence required by Independence Standards Board Standard No. $1 ; \ldots$

- the report of the audit committee also include a statement by the audit committee whether, based on the review and discussions noted above, the audit committee recommended to the Board of Directors that the audited financial statements be included in the company's Annual Report ...;

- companies disclose in their proxy statements whether their Board of Directors has adopted a written charter for the audit committee, and if so, include a copy of the charter as an appendix to the company's proxy statements at least once every three years;

The New York Stock Exchange (NYSE) has required, since 1978, listed companies to have only independent directors on audit committees. While the NYSE rules prohibited officers, employees and affiliates of the company from serving as audit committee members, there was still room for many "grey" directors to be on the audit committee. "Grey" directors include relatives of management, executives from customer 
or supplier companies, bankers and business consultants, retired executives, as well as interlocking directors. Vicknair et al. (1993) find that 74 percent of the audit committees in their sample had at least one "grey" director; further, in 26 percent of their sample companies "grey" directors constituted a majority of the audit committee. The SEC (1999b) addressed this issue, by requiring that companies:

"disclose in their proxy statements whether the audit committee members are "independent" as defined in the applicable listing standards, and disclose certain information regarding any director on the audit committee who is not "independent"."

The SEC continued to act to enhance the quality of audit committees. As part of the rule on auditor independence, the SEC (2000) modified the rule related to audit committees' interactions with the external auditor. Specifically, the SEC (2000) noted that:

"We have modified the proposed disclosure to require disclosure only of whether the audit committee considered whether the principal accountant's provision of the information technology services and other non-audit services to the registrant is compatible with maintaining the principal accountant's independence. ... Investors will be aided by knowing whether the company's audit committee considered whether the provision of nonaudit services by the company's principal accountant is compatible with maintaining the accountant's independence."

The sudden bankruptcy of Enron, coupled with the demise of Andersen and the problems at WorldCom, led to the enactment of the Sarbanes Oxley Act (SOX) of 2002; multiple sections of SOX deal with the composition and functioning of audit committees.

Section 301 of SOX (2002) is titled "Public Company Audit Committees" and states as follows:

"(m) Standards Relating to Audit Committees.--

"(1) Commission rules.-- 
"(A) In general.-Effective not later than 270 days after the date of enactment of this subsection, the Commission shall, by rule, direct the national securities exchanges and national securities associations to prohibit the listing of any security of an issuer that is not in compliance with the requirements of any portion of paragraphs (2) through (6)....

(2) Responsibilities relating to registered public accounting firms.--The audit committee of each issuer, in its capacity as a committee of the board of directors, shall be directly responsible for the appointment, compensation, and oversight of the work of any registered public accounting firm employed by that issuer (including resolution of disagreements between management and the auditor regarding financial reporting) for the purpose of preparing or issuing an audit report or related work, and each such registered public accounting firm shall report directly to the audit committee.

"(3) Independence.--

"(A) In general.--Each member of the audit committee of the issuer shall be a member of the board of directors of the issuer, and shall otherwise be independent.

"(B) Criteria.--In order to be considered to be independent for purposes of this paragraph, a member of an audit committee of an issuer may not, other than in his or her capacity as a member of the audit committee, the board of directors, or any other board committee-

"(i) accept any consulting, advisory, or other compensatory fee from the issuer; or

"(ii) be an affiliated person of the issuer or any subsidiary thereof.

"(C) Exemption authority.--The Commission may exempt from the requirements of subparagraph (B) a particular relationship with respect to audit committee 
members, as the Commission determines appropriate in light of the circumstances.

As required by Section 301 of SOX, the SEC issued a rule proposal and then the final rules relating to audit committee director independence in 2003. The final SEC (2003) rules state as follows:

(i) Each member of the audit committee must be a member of the board of directors of the listed issuer, and must otherwise be independent; provided that, where a listed issuer is one of two dual holding companies, those companies may designate one audit committee for both companies so long as each member of the audit committee is a member of the board of directors of at least one of such dual holding companies.

(ii) Independence requirements for non-investment company issuers. In order to be considered to be independent for purposes of this paragraph (b)(1), a member of an audit committee of a listed issuer that is not an investment company may not, other than in his or her capacity as a member of the audit committee, the board of directors, or any other board committee:

(A) Accept directly or indirectly any consulting, advisory, or other compensatory fee from the issuer or any subsidiary thereof, provided that, unless the rules of the national securities exchange or national securities association provide otherwise, compensatory fees do not include the receipt of fixed amounts of compensation under a retirement plan (including deferred compensation) for prior service with the listed issuer (provided that such compensation is not contingent in any way on continued service); or

(B) Be an affiliated person of the issuer or any subsidiary thereof.

Thus, while the SEC has urged public companies to have audit committees since at least 1940, the requirements for the composition of the committee have gradually changed in recent years. Further, the rules related to audit committee director independence have evolved in recent years culminating in the legal requirements of SOX. 
However, even now, the SEC has left the actual definitions of director independence to the specific listing rules of the NYSE, AMEX, and NASDAQ stock exchanges. Raghunandan and Rama (2007) note that there continues to be substantial variation among the listing requirements related to independence; there are instances when firms stated that their members were independent, yet disclosed transactions between the firm and the audit committee director(s) under the "Certain Relationships" section of the proxy statement. Nevertheless, following the SEC's implementation of the SOX related requirements for audit committee director independence, researchers have rarely used director independence as a factor in research related to U.S. public companies.

\section{Audit Committee Director Expertise}

Regulators and legislators have started to push for qualifications beyond independence in recent years. Thus, for example, the Blue Ribbon Committee (1998) noted the need for audit committee directors to be financially literate; financial literacy was defined as "the ability to read and understand fundamental financial statements, including a company's balance sheet, income statement and cash flow statement".

It is interesting to note that while SOX mandates audit committee director independence, it does not have a similar mandate for the financial expertise of audit committee directors. Section 407 of SOX is titled "Disclosure of Audit Committee Financial Expert" and reads as follows:

(a) Rules Defining "Financial Expert".--The Commission shall issue rules, as necessary or appropriate in the public interest and consistent with the protection of investors, to require each issuer, together with periodic reports required pursuant to sections 13(a) and 15(d) of the Securities Exchange Act of 1934, to disclose 
whether or not, and if not, the reasons therefor, the audit committee of that issuer is comprised of at least 1 member who is a financial expert, as such term is defined by the Commission.

(b) Considerations.-- In defining the term "financial expert" for purposes of subsection (a), the Commission shall consider whether a person has, through education and experience as a public accountant or auditor or a principal financial officer, comptroller, or principal accounting officer of an issuer, or from a position involving the performance of similar functions-

(1) an understanding of generally accepted accounting principles and financial statements;

(2) experience in--

(A) the preparation or auditing of financial statements of generally comparable issuers; and

(B) the application of such principles in connection with the accounting for estimates, accruals, and reserves;

(3) experience with internal accounting controls; and

(4) an understanding of audit committee functions.

(c) Deadline for Rulemaking.--The Commission shall--

(1) propose rules to implement this section, not later than 90 days after the date of enactment of this Act; and

(2) issue final rules to implement this section, not later than 180 days after that date of enactment.

In accordance with Section 407 of SOX, the SEC proposed rules related to the disclosure of audit committee financial experts. The initial proposal defined the term “financial expert" as follows: (SEC 2002a)

"a person who has, through education and experience as a public accountant, auditor, principal financial officer, controller or principal accounting officer, of a company that, at the time the person held such position, was required to file reports pursuant to Section 13(a) or 15(d) of the Exchange Act, or experience in one or more positions that involve the performance of similar functions (or that results, in the judgment of the company's board of directors, in the person's having similar expertise and experience), the following attributes: 
(1) An understanding of generally accepted accounting principles and financial statements;

(2) Experience applying such generally accepted accounting principles in connection with the accounting for estimates, accruals, and reserves that are generally comparable to the estimates, accruals and reserves, if any, used in the registrant's financial statements;

(3) Experience preparing or auditing financial statements that present accounting issues that are generally comparable to those raised by the registrant's financial statements;

(4) Experience with internal controls and procedures for financial reporting; and

(5) An understanding of audit committee functions."

However, this proposal evoked significant opposition. Specifically, many commenters believed that the proposed definition of "audit committee financial expert" was unduly restrictive, and noted that many public companies would have a difficulty attracting qualified audit committee financial experts. News stories in the media noted that under the proposed definition, even eminent personalities such as the Chairman of the Federal Reserve (Alan Greenspan) or one of the richest investors in the world (Warren Buffett) would not qualify as "audit committee financial expert" since they did not have experience in "preparing” financial statements (Bryan-Low 2002).

In light of such criticism, the SEC (2003a) revised the definition of an audit committee financial expert as follows: a person who understands GAAP; has an ability to assess the application of GAAP in association with estimates, accruals and reserves; has experience in the preparation, audit, analysis and evaluation of financial statements or has 
experience in active supervision of such a person; has an understanding of internal controls and an understanding of the audit committee functions.

Further, the SEC rules require that if a company discloses that it does not have an audit committee financial expert, it must also explain why it does not have such an expert. William H. Donaldson, the Chairman of the SEC, noted in congressional testimony that "these disclosures will improve transparency to investor in evaluating the experience of the audit committees of companies in which they invest" (Donaldson 2003).

How difficult has it been for public companies to obtain qualified "audit committee financial experts?" Williams (2005) examines proxy disclosures by 489 firms (of which 370 were S\&P 500 firms) and finds that more than 95 percent of all firms (including the smaller, non-S\&P 500 firms) disclose the presence of at least one audit committee financial expert. Interestingly, 46 percent of the sample firms disclose the presence of two or more financial experts. Similarly, Carcello et al. (2006) find, using a sample of 400 companies, that 98 percent of the companies make the required financial expert disclosure; about 30 percent of companies had an increase in the number of experts since the passage of SOX. Krishnan and Lee (2009) examine why some firms choose to disclose more than one audit committee financial expert, as well as the choice between different types of experts. Their analysis of 802 firms (3,218 audit committee directors) indicates that about 60 percent of firms have has one or more accounting financial experts (as opposed to other types of "audit committee financial experts") on the audit committee; further, firms in a high-litigation environment were more likely to have accounting financial experts on their audit committees. 
Does the market value the presence of accounting experts on the audit committee? The evidence in Davidson et al. (2004) and DeFond et al. (2005) suggests that there is a positive market reaction when companies hire audit committee directors with financial expertise.

Prior Research

Audit Committee Processes

Cohen et al. (2002) provide evidence about the functioning of audit committees on the basis of interviews with 36 auditors. The authors report that most respondents believe that "management is the primary driver of corporate governance" and that many auditors viewed audit committees as not sufficiently strong. However, this study was conducted prior to SOX; in a follow-up study, Cohen et al. (2007) interview 38 auditors after the enactment of SOX. Cohen et al. (2007) report that audit committees are more powerful, active and diligent post-SOX.

Gendron and Bedard (2006) examine the "black box" related to the functioning of audit committees. How do the directors develop and sustain audit committee effectiveness? These authors interviewed 22 individuals in three large Canadian public corporations, spending between 45 to 75 minutes with each individual. The authors suggest that the meaning of committee effectiveness is based on the reflection of processes and activities around audit committee meetings.

Beasley et al. (2009) examine the "substance versus symbolism" issue by conducting detailed interviews with 42 individuals serving on audit committees of U.S. public companies. The authors find that many of the respondents seek to provide 
effective monitoring of financial reporting and avoid serving on ceremonial audit committees. Importantly, the authors report that many of the responses vary with the individual characteristics of the respondents as well as the time of appointment of the director (pre- or post-SOX).

\section{Audit Committee Interaction with External Auditors}

As previously noted, the primary role of the audit committee is to provide oversight over the financial reporting process. Hence, the audit committee must have unfettered and effective interactions with external auditors. I now turn to studies that examine the interaction between audit committees and external auditors.

Financial statements are, ultimately, the product of negotiations between management and the external auditor. An effective audit committee must, therefore, provide strong support to external auditors if the aim is to have high quality financial reporting. Such support is particularly important in situations involving professional judgments; this is because it is precisely in those areas that disagreements between management and auditors are bound to occur.

Does audit committee composition affect the extent of support received by external auditors in difficult situations? Carcello and Neal $(2000,2003)$ examine one such situation: when the auditor is considering the issuance of a going-concern modified audit opinion. Carcello and Neal (2000) find that there is a significant negative association between the percentage of affiliated directors on the audit committee and the likelihood of a going-concern modified audit opinion for financially stressed firms. This suggests that audit committee composition can influence the support received by external auditors. 
In a follow-up study, Carcello and Neal (2003) examine the association between audit committee independence and auditor dismissal following the issuance of a new going-concern modified audit report. Since managements usually do not like receiving a going-concern modified audit opinion, they may retaliate against the auditor by dismissing an auditor who issues a going-concern modified audit opinion, particularly if the company subsequently does not fail—that is, if ex-post, the opinion can be viewed as "erroneous." Using a sample of companies receiving an initial going-concern modified audit opinion, Carcello and Neal (2003) find that in companies with audit committees that have fewer affiliated directors an auditor dismissal is less likely following the issuance of a new going-concern modified audit opinion.

DeZoort et al. (2003) examine audit committee support to the external auditor using responses obtained from 55 audit committee directors. In the experimental task, respondents evaluated judgments about materiality and accounting precision in situations involving auditor-management differences. The results indicate that audit committees that include members with financial expertise experience are more likely to support external auditors in such disputes with management. In a later experiment, DeZoort et al. (2008) compare audit committee director responses before and after SOX; these authors find that audit committee members are likely to support the external auditor, when there is auditor-client differences related to proposed adjustments, in the post-SOX period when compared to the results from the pre-SOX study.

Cohen and colleagues conducted two surveys of auditors and audit committee directors to elicit information about the underlying audit committee processes. In Cohen et al. (2010) the interview subjects are auditors; the authors note that "auditors report that 
the corporate governance environment has improved considerably in the post-SOX era with audit committees that are substantially more active, diligent, knowledgeable, and powerful." In a later study, Cohen et al. (2013) report findings from interviews of audit committee directors. The authors note that there is a marked difference in the monitoring role of the audit committee in the post-SOX period. Specifically, the subjects reported increased interaction between the audit committee and the external auditor, as well as heightened attention to matters of audit and financial reporting addressed in such interactions.

Another stream of research examines the association between audit committee characteristics and auditor changes. Archambeault and DeZoort (2001) examine the association between "suspicious" auditor changes and audit committee characteristics. Using a sample of 30 U.S. public companies that had suspicious audit switches and a matched sample of 30 companies without such auditor switch during the period 19941996, the authors find that companies with a suspicious auditor switch are less likely to have audit committee directors with accounting or finance expertise. Owens-Jackson et al. (2009) examine the association between audit committee characteristics and auditor changes subsequent to events such as: disagreement with management, resignation of the auditor, disagreement over audit fees, and non-standard audit opinions. Their sample includes 60 firms with such auditor changes during the years 1993-2001. The results from Owens-Jackson et al. (2009) suggest that such auditor changes are less likely in the presence of an audit committee that is more independent and has more financial expertise. 


\section{Audit Fees}

There is an extensive literature on the determinants of audit fees. The seminal paper in this area is by Simunic (1980), whose research was motivated by questions about the extent of competition in the market for audit services. In light of congressional hearings about the dominance of the (then) Big Eight accounting firms, Simunic (1980) examined clients' audit fees. For this exercise, he came up with a model of audit fees that includes variables proxying for client size, business complexity, audit risk, and auditor type. Variants of the model used by Simunic (1980) have been used by almost all subsequent research that has audit fees as the focus of analysis. In particular, the log-log model (where the dependent variable is the natural logarithm of audit fees, and client size is measured by the natural logarithm of client assets) owes its origin to Simunic (1980).

Simunic's model was subsequently refined by many other researchers, and used for examining other policy-issues related to the market for audit services. For example, Francis and Simon (1987) examine audit pricing for small clients. Using data from 210 publicly traded companies, the authors find that there is an audit fee premium for the Big eight firms. In addition, data from a sub-sample of initial audit engagements show that there is significant discounting of audit fees for initial audit engagements when compared to continuing engagements. This notion of low-balling of audit fees is examined further in Simon and Francis (1988). Using data from 214 clients changing auditors, and 226 clients without an auditor change, the authors find that there is a significant initial year audit fee discount; the average discount is 24 percent fee in the initial engagement year and 15 percent for the two subsequent years. The fee reverts back to "normal" levels by the fourth year of the engagement. 
A natural extension of the "Big N premium" is to see if such premiums are found in other countries, and also if there are differences within the Big Eight firms. One area that has received significant attention is industry specialization by audit firms. Craswell et al. (1995) use Australian data and find that, apart from a Big Eight fee audit fee premium, there is also a significant premium for industry specialist Big 8 auditors compared to non-specialist Big 8 auditors. Defond et al.(2000) examine the audit fees of publicly listed companies in Hong Kong using 348 publicly listed companies from 1992. These authors find that there is both a Big 6 audit firm premium and an industry specialist auditor premium. Another strand of research examines if the differences between firms can be extended to differences between offices within firms. That is, is industry specialization at the national level or is it more appropriately classified at the city (or MSA) level? Ferguson et al. (2003) find, using data from clients of Big 5 firms in Australia, that if an auditor is both city specific industry leader and a national level industry specialist, there is a significant audit fee premium; in contrast, there is no fee premium for auditors who are not city-level specialists.

Hay et al. (2006) conduct a meta-analysis of prior research related to the determinants of audit fees. The analysis suggests that while the specific variables may vary across studies and countries, in general variables proxying for the following broad characteristics are associated with audit fees: client size, business complexity, financial condition, audit risk, auditor type, as well as variables related to the executives and audit committee of the client. 


\section{Audit Fees and Client Risk Measures}

Many studies show that audit fees are related to various proxies for client risk. Bell et al. (2001) use confidential work-papers related to the audits of 422 clients conducted by a large accounting firm in 1989. The authors show that audit fees are positively related to the auditor-assessed level of client business risk. They note that the increase in audit fees arises solely out of additional hours worked, as there was no change in the hourly billing rate. Bedard and Johnstone (2004) find similar results using data provided by a large audit firm. The data used in their analyses are derived from engagement partners' assessments of clients made during the participating firm's 20002001 client continuance risk assessment process. The authors find a positive association between earnings manipulation risk and both audit hours and hourly billing rates.

Abbott et al. (2006) use data from 429 non-financial clients of the Big 5 firms during 2000, and find a significant positive association between the level of audit fees and the direction of discretionary accruals. Income-increasing (income-decreasing) discretionary accruals are positively associated with higher (lower) audit fees, suggesting that auditors consider client risk when pricing engagements. Charles et al. (2010) report similar results using a proprietary measure of financial reporting risk as the variable of interest; this risk measure is positively related to audit fees, in a sample consisting of 4,320 firm-years from Big 5 clients during the 2000-2003 period.

Venkataraman et al. (2008), using data from 142 firms that go public between January 1, 2000 and December 21, 2002, find that audit fees are higher for IPO engagements as compared to post-IPO engagements; this again suggests that audit fees are higher when the auditor anticipates a higher risk associated with the client. Feldmann 
et al. (2009) examine audit fees for 228 clients restating prior financial statements during 2004-2005. These authors find that audit fees are higher for their sample of restating firms when compared to a control sample of non-restating firms. The authors suggest one explanation for the fee premium is the auditor's perception of an increase in risk associated with the audit. Munsif et al. (2011) analyze the audit fees of 1,610 SEC registrants that remediated previously disclosed internal control weaknesses during the years 2004 to 2007. The authors document that while audit fees are lower for firms that remediate such weaknesses opposed to firms that do not remediate, the fee premium associated with the adverse internal control report persists for three years after the remediation. These findings suggest that auditors indeed factor client risk into the pricing of the audit.

In summary, prior research provides evidence that audit fees are associated with the auditor's assessed level of client risk. Further, audit committees constitute an important element of a company's overall control environment. Hence, the characteristics of the audit committee directors can be expected to be a significant factor in the external auditor's assessment of client risk and, thus, audit fees.

\section{Association between Audit Committee Composition and Audit Fees}

Given the requirement in SOX that the audit committee be responsible for the selection and compensation of the audit committee, it is likely that characteristics of the audit committee will be associated with audit fees. This relationship was likely even before SOX, given that the audit committee is an important component of the governance mechanism of a company and, hence, constituted an important element in the overall 
client risk assessment by the external auditor. Accordingly, some prior studies have examined the association between audit committee characteristics and the external audit fees.

Carcello et al. (2002) examine the association between governance mechanisms and audit fees. The data in their study are based on a questionnaire sent to controllers of Fortune 1000 companies, and rely on audit fees paid during the period from April 1992 to March 1993. The results show that audit committee characteristics, such as audit committee independence and expertise, have a positive relationship with audit fees. While the data in Carcello et al. (2002) are based on surveys, Abbott et al. (2003a) use data publicly disclosed by companies (subsequent to the SEC's November 2000 rule mandating such disclosure in proxy statements filed with the Commission on or after February 5, 2001). These authors find that audit committees that have only independent members and has members with financial expertise are more likely to demand increased scope of auditing services from their external auditors, which in turn results in higher audit fees. In a related study, Abbott et al. (2003b) examine the association between audit committee characteristics and the relative magnitude of nonaudit services (NAS) fees paid to incumbent auditors. The results indicate that the nonaudit fee ratio is lower in companies that have audit committees with only independent directors and higher meeting frequency.

Goodwin-Stewart and Kent (2006) examine whether the presence of an audit committee, as well as specific audit committee characteristics, are associated with higher audit fees. The data are from 401 firms listed on the Australian Stock Exchange in October 2000. These authors find that audit committee expertise is associated with higher 
audit fees. Hoitash and Hoitash (2008), using data from 2,393 firms during 2004, find that a strong audit committee usually demands a higher level of assurance and less is likely to dismiss its auditors.

\section{Research Question}

Prior research suggests that audit fees are influenced by audit committee characteristics because of the significant role played by the audit committee in the financial reporting process. However, such prior studies have primarily focused on audit committee director independence and financial expertise, and diligence of the audit committee.

As noted by Carcello et al. (2011), the audit committee chair plays an important role in the monitoring of corporate financial reporting. Hence, it is likely that a change in the audit committee chair will be associated with changes in audit fees. One argument is that the appointment of a new audit committee chair could increase the auditor's assessment of inherent risk; this, in turn, could lead to more effort (to reduce the detection risk) and hence lead to higher audit fees. Alternatively, a new audit committee chair could demand a higher level of assurance, which also would lead to higher audit fees. Conversely, if the new audit committee chair believes that the audit fees are "excessive" then there could be a demand to reduce audit fees. Ultimately, it is an

empirical question if the appointment of a new audit committee chair leads to higher or lower audit fees. Hence, I frame the research question in the null form as follows: RQ1: Is there an association between audit fees and the change in the audit chair? 
Method

The following regression model was used to test the first research question:

$$
\begin{aligned}
\operatorname{Ln}(\text { AuditFees })= & \beta_{0}+\beta_{1} * \operatorname{Ln}(\text { TotalAssets })+\beta_{2} * \text { InvRecTA }+\beta_{3} * \text { Foreign }+\beta_{4} * \text { SqrtSeg } \\
& +\beta_{5} * \text { CurrentRatio }+\beta_{6} * \text { Loss }+\beta_{7} * \text { Leverage }+\beta_{8} * \text { Big } 4 \\
& +\beta_{9} * \text { GCOpinion }+\beta_{10} * \text { Initial }+\beta_{11} * \text { ICW }+\beta_{12} * \text { ACCC }+\varepsilon
\end{aligned}
$$

$$
\begin{aligned}
\operatorname{Ln}(\text { AuditFees })= & \beta_{0}+\beta_{1} * \operatorname{Ln}(\text { TotalAssets })+\beta_{2} * \text { InvRecTA }+\beta_{3} * \text { Foreign }+\beta_{4} * \text { SqrtSeg } \\
& +\beta_{5} * \text { CurrentRatio }+\beta_{6} * \text { Loss }+\beta_{7} * \text { Leverage }+\beta_{8} * \text { Big } 4 \\
& +\beta_{9} * \text { GCOpinion }+\beta_{10} * \text { Initial }+\beta_{11} * \mathrm{ICW}+\beta_{12} * \mathrm{BD}+\beta_{13} * \mathrm{NM}+\varepsilon
\end{aligned}
$$

The variables are defined as follows:

$$
\begin{aligned}
\operatorname{Ln}(\text { AuditFees }) & =\text { Natural logarithm of audit fees; } \\
\text { Ln(TotalAssets) } & =\text { Natural logarithm of total assets; } \\
\text { InvRecTA } & =\text { Inventory plus accounts receivable as a proportion of total assets; } \\
\text { Foreign } & =\text { I if company has foreign operations, } 0 \text { otherwise; } \\
\text { SqrtSeg } & =\text { Square root of the number of segments; } \\
\text { CurrentRatio } & =\text { Ratio of current assets to current liabilities; } \\
\text { Loss } & =1 \text { if company has a loss before extraordinary items, } 0 \text { otherwise; } \\
\text { Leverage } & =\text { Ratio of total liabilities to total assets; } \\
\text { Big4 } & =1 \text { if the auditor is a Big } 4 \text { audit firm, } 0 \text { otherwise; } \\
\text { GCOpinion } & =1 \text { if the firm receives a going concern opinion, } 0 \text { otherwise; } \\
\text { Initial } & =1 \text { if the audit engagement is the first year audit, } 0 \text { otherwise; } \\
\text { ICW } & =1 \text { if the firm has a material internal control weakness (disclosed }
\end{aligned}
$$


pursuant to SOX 404), 0 otherwise;

$\mathrm{ACCC}=1$ if there was a change in the Audit Committee Chair, 0 otherwise;

$\mathrm{BD}=1$ if new Audit Committee Chair was previously a member of the audit committee, 0 otherwise;

$\mathrm{NM}=1$ if new Audit Committee Chair was previously a member of the board (but not on audit committee), 0 otherwise;

The natural log of audit fees (Ln[AuditFees]) is used as the dependent variable, which is consistent with prior research in the auditing literature. Typically, the estimation model that has been used in prior research regresses audit fees against a number of measures that are hypothesized to relate to audit fees.

The natural $\log$ of total assets $(\operatorname{Ln}[$ TotalAssets] $)$ is used as a proxy for firm size. Prior Research going all the way back to Simunic (1980) has found a strong correlation between total assets and audit fee because larger firms require greater time and effort in their audits due to the size and scope of their business operations. It is therefore expected that the coefficient of Ln(TotalAssets) will be positive.

Inventory and accounts receivables as a proportion of total assets (InvRecTA), foreign operations (Foreign) and the square root of segments (SqrtSeg) are included in the model because they are all considered to be measures of complexity that have an impact on audit fees. All three of these control variables are expected to have a positive coefficient.

Five of the other variables used in the models control for client risk and include the following; Current Ratio (CurrentRatio), Net Loss before extraordinary items (Loss), Financial Leverage (Leverage), Going Concern Opinion (GCOpinion), and Internal 
Control Weakness (ICW). All of these variables are expected to have positive coefficients.

Big4 is included in the models because prior research has found that the largest international public accounting firms charge a premium for their audit services. It is therefore expected that Big4 will have a positive coefficient. Additionally, prior research has found that audit fees are discounted in the initial years of an audit engagement (e.g. Simon and Frances 1988; Whisenant et al. 2003). Initial is included in the model and is expected to have a negative coefficient.

The remaining variables in the models relate to the change in the audit committee chair as well as indicate the role of the individual prior to becoming the chair. The change in the audit committee chair variable (ACCC) indicates if a change has taken and board member $(B D)$ as well as not a member of the board $(N M)$ indicate prior roles if a change took place.

Sample

I begin the sample selection process using all 3,417 companies from the 2009 Corporate Library Company Data file. I eliminate foreign companies (173), companies with fiscal year-end not around 12/31 (809), and companies in the financial, insurance, or real estate sector (603). This resulted in a sample of 1,832 companies for which Corporate Library director information was available. I then compare the 2009 Corporate Library Directors Data file to the 2008 file for the 1,832 companies.

I use the information from the 2009 and 2008 Corporate Library Directors Data files to determine which audit committee chairs in 2009 were not audit committee chairs 
in 2008. This comparison indicates that there are 339 firms, which had a new audit committee chair in 2009. The audit committee chairs in 2009 that were not chairs in 2008 were also identified as to their role on the board in 2008 (that is, whether the new chair was already an audit committee member, board member but not an audit committee member, or not a member of the board).

For the 1,832 companies, I obtain financial data from Compustat database, and audit related data (name of the audit firm, audit fees, audit opinion, and internal control opinion) from Audit Analytics database. There were 70 companies with missing financial data resulting in a sample size of 1,762 companies for the audit fee model. Table 1 provides details of the sample selection.

Results

\section{Descriptive Statistics}

Table 2 provides the descriptive statistics for the variables used in the regression model. The mean audit fee for the sample companies is $\$ 2.597$ million while the median is $\$ 1.300$ million. The mean and median of total assets are $\$ 512$ million and $\$ 77$ million, respectively. Both of these distributions appear to be highly skewed, so consistent with prior research, the natural logarithm is used to transform both audit fees and total assets. The mean and median of the ratio of inventory and accounts receivable to total assets is 0.21 and 0.17 , respectively. On average, the companies in the sample data have about 2 segments, consistent with the data from prior studies. The mean and median of the current ratio for the sample data is 2.56 and 1.81 respectively. Slightly more than half of the companies had foreign operations. . About 5 percent of the companies had a going 
concern modified audit opinion, while about 3 percent of the companies had an internal control weakness. Given that the sample includes a significant amount of large companies, it was not unexpected that over 84 percent were audited by a Big 4 accounting firm. Less than 5 percent of the companies in sample had an audit engagement that was the first year of the audit. About 19 percent of the companies had a change in the audit committee chair, with about 11 percent of those individuals not being on the board the prior year.

\section{Regression Results}

The regression results using Ln(AuditFees) as the dependent variable and ACCC as the variable of interest are presented in the first three columns of Table 3 (Model 1). The overall regression model is significant $(\mathrm{p}<0.001)$ with an adjusted $\mathrm{R}^{2}$ of 75 percent. The same can be said for the regression results using Ln(AuditFees) as a dependent variable and $\mathrm{BD}$, and $\mathrm{NM}$ as the variables of interest, the results of which are presented in the last three columns of Table 3 (Model 2).

All the control variables in the two models (except for CurrentRatio and Initial) are significant and have the expected coefficient signs. The variables of interest (ACCC, and $\mathrm{BD}$ ), which are the variables associated with the change in the audit committee chair, all have positive coefficients and all are significant $(\mathrm{p}<.05)$. NM is a variable of interest that missed being significant by a small amount $(\mathrm{p}=.062)$. These results indicate that audit fees are higher when an audit committee has a new chair regardless of the new chairs prior involvement with the company's board. In terms of effect size, a new Audit Committee Chair is associated with an increase of about 11 percent in audit fees. Since a 
new audit committee chair will typically review with greater detail, require clarifications, or question previous decisions related to the audit, the audit fee will be higher.

Summary

Regulators and legislators have recognized that audit committees constitute an important element in the corporate financial reporting process. The interaction between the audit committee and external auditors is important in ensuring high quality financial reporting. While prior studies have examined the association between some audit committee characteristics and audit fees, the role of the audit committee chair has not been investigated in such studies. More generally, there is little archival research related to the role played by the audit committee chair in the oversight of financial reporting process.

The first part of the dissertation investigates the association between the audit committee chair change and audit fees. This part of the dissertation adds to the body of research on audit committees and audit fees and documents the significance of the role played by the audit committee chair in the external financial reporting process. 


\section{AUDIT CHAIR CHANGE AND AUDIT REPORT LAGS}

Motivation

Audit report lag is measured by comparing the company's fiscal year-end date to the date of the external audit report. Since many of the audit procedures are performed after the fiscal year end, audit report lag is considered a proxy for audit effort; in addition, prior research has documented such association between incremental audit effort and the audit report lag. A number of factors have been found to effect audit report lag including client size and other characteristics (such as financial condition, industry membership, etc.), auditor characteristics, and auditor change.

The second part of the dissertation investigates the association between the audit committee chair change and audit report lags. This part of the dissertation will add to the body of research on the association between audit committees and audit report lags by determining the significance of the role played by the audit committee chair.

\section{Background}

Regulators and legislators have long been concerned about the need for the timely disclosure of information. This is because late disclosure of financial information can lead to higher degree of information asymmetry (Hakansson 1977). This explains the significant negative market reaction associated with late disclosure of financial information (Chambers and Penman 1984; Easton and Zmijewski 1993). Thus, for example, the SEC has rules about the time within which registrants must file their periodic financial statements with the commission. Starting in 1946 (1970), the deadline 
was 90 (45) days to file the Form 10-K (10-Q) with the Commission. The SEC also requires that registrants that are unable to file annual or quarterly statements by the applicable deadlines file a notice of non-timely filings (Form NT filings) with the Commission.

Such focus on timely reporting has also been reflected in legislative actions. For example, Section 409 of the Sarbanes-Oxley Act (SOX 2002) authorized the SEC to require registrants to disclose, "... on a rapid and current basis such additional information concerning material changes in the financial condition or operations of the issuer."

Consistent with SOX, the SEC initially proposed to reduce the filing deadlines; however, there was strong opposition to such reduction in filing deadlines from both company managements and their auditors. In the face of opposition, the SEC modified the rules by creating different classes of filers with differing deadlines (SEC 2002, 2005). The SEC now requires large-accelerated filers (i.e., public companies with public float of \$700 million or more) and accelerated filers (i.e., public companies with public float between $\$ 75$ million and $\$ 700$ million) to file their annual reports within 60 and 75 days, respectively, of the fiscal year end for fiscal year ends on or after December 15, 2006; non-accelerated filers continue to have a 90 day deadline to file their annual reports with the SEC (SEC 2005). Both accelerated and large accelerated filers had filing deadlines of 75 days for fiscal year ends between December 15, 2003 and December 14, 2006; this was further reduced to 60 days, for large accelerated filers, for fiscal year ends on or after December 15, 2006. 
In addition, the SEC's Rule $12 \mathrm{~b}-25$ requires that registrants that fail to timely file their quarterly or annual reports (i.e., $10-\mathrm{Q}$ or $10-\mathrm{K}$ ) with the Commission notify the Commission with an appropriate Form NT (i.e., "Non-Timely") no later than one day after the due date of the filing. Such Form NT filings lead to an automatic one-time extension of 5 days for 10-Qs and 15 days for 10-Ks. Registrants that later file their 10-Q or 10-K before the extended deadline are deemed to have filed on a timely basis, but those that do not file within the extended deadline are subject to penalties including deregistration by the SEC and delisting by stock exchanges, which in turn leads to inability to raise capital through public securities. Thus, registrants have incentives to file annual reports with the SEC on a timely basis; this in turn means that auditors have incentives to complete their audits on a timely basis, i.e., to ensure that audit report lag is not excessive.

Prior Research

Determinants of Audit Report Lag

Given the importance of audit report lag, many prior studies have examined the determinants of audit report lag (Ashton et al. 1987, Ashton et al.1989, Newton and Ashton 1989, Kinney and McDaniel 1993, Bamber et al. 1993, and Schwartz and Soo 1996, Henderson and Kaplan 2000, Knechel and Payne 2001). The above studies examine data from the pre-SOX period; studies that have examined audit report lag in the post-SOX period include Ettredge et al. (2006), Krishnan and Yang 2009), and Tanyi et al. (2010). 
Ashton et al. (1987) is the first study that seeks to explain the determinants of audit report lag in terms of client and auditor characteristics. These authors collected data from surveys mailed to managing partners of U.S. offices of Peat, Marwick, Mitchell \& Co. The data are for audit engagements in 1982. Ashton et al. (1987) find that, as expected, good internal controls and the performance of interim audit work are associated with shorter audit report lag. However, public traded companies, busy season (i.e., December 31) fiscal year-end, and qualified audit opinions are associated with longer audit report lag. In a subsequent study, Ashton et al. (1989) examine audit report lag using data from 465 Canadian public companies listed on the Toronto Stock Exchange. Their results show that auditor type (Big 8 or not), bottom line loss, extraordinary items on the income statement, and the presence of contingencies are related to the audit report lag.

During the late 1980s, many auditing researchers were interested with the extent of judgment versus structure in the audit approaches of large international audit firms. Some prior studies have examined the association between the use of structure versus judgment in audit approaches and various audit-related processes and outcomes. Thus, for example, Williams and Dirsmith (1988) examine the association between audit technology and audit report lag; the hypothesis in their study is that such differences in audit approaches can lead to differences in audit efficiency and thus can be a significant factor in explaining when the auditors complete an audit engagement (i.e., affect the audit report lag). Williams and Dirsmith (1988) use data from 679 companies with financial statement and earnings announcement data from the Compustat and IBES databases, respectively. Consistent with other studies, the construct of audit technology is measured 
as the relative degree of structure versus judgment of a CPA firm's audit technology. The results indicate that firms employing a structured audit approach have, ceteris paribus, shorter audit report lags and that clients of such auditors have shorter earnings announcement lags.

Bamber et al. (1993) re-visit the association between audit approaches and audit report lag. They find, using a sample of public companies during the period from 1983 to 1985, that audit firms employing a structured audit approach have shorter audit report lag.

It is likely that special situations, such as those related to an auditor change, would have a significant effect on the audit report lag. In particular, auditor changes that occur late during a fiscal year can be expected to have a longer audit report lag; this is because there is less time for the auditor to get to know the client and understand the business and processes of the client. Schwartz and Soo (1996) examine the association between the timing of auditor change (that is, how long before the fiscal year end did the auditor change happen) and the audit report lag with the incoming auditor. Their sample includes 502 firms with auditor changes between 1988 and 1993. Schwartz and Soo (1996) find that firms that switch auditors earlier (later) in the fiscal year tend to have shorter (longer) audit report lag.

Knechel and Payne (2001) examine some other factors that could arguably affect the audit report lag. These factors are: audit effort measured by the number of actual hours invested in the engagement, the allocation of the audit team members by rank, and the provision of non-audit services. These authors obtain proprietary data related to 226 clients from a large audit firm. Knechel and Payne (2001) show that there is a significant 
positive association between audit effort, the use of inexperienced audit staff and audit report lag. However, the provision of non-audit services is negatively associated with audit report lag, presumably because of the benefits from synergy.

All of the above referenced studies examine audit report lags in the pre-SOX period. SOX fundamentally changed the environment of auditing. In addition, Section 404 of SOX led to significant changes in the audit approaches of firms. Given the emphasis in SOX about internal controls, Ettredge et al.(2006) examine the association between internal control quality and audit report lags in the post-SOX period. Their analyses use 2,344 firms with SOX 404 data on internal controls for the first year of such internal control reporting (2004). These authors find that, as expected, there is a significant increase in audit report lag after SOX. Consistent with expectations, the authors also find that firms with material weakness in internal control have significantly longer audit report lag. Krishnan and Yang (2009) examine the trend in audit report lags before and after the enactment of SOX. The authors report that audit report lag "increased significantly in the two-year period 2001-2002 prior to the introduction of the accelerated filing requirements and in the period 2003-2006 when the new filing requirements were in effect."

Tanyi et al. (2010) examine audit report lags for different types of auditor changes. Specifically, given the sudden demise of Arthur Andersen, they examine audit report lags for ex-Andersen clients and other client that changed auditors. The results indicate that the audit report lag is significantly higher for ex- Andersen clients (that did not follow their Andersen partner to the new audit firm) than for clients voluntarily changing auditors from another Big 5 predecessor for the fiscal year ended December 31, 
2002; interestingly, the differences in audit reporting lags between the two groups are not significant for the fiscal years 2000 (the last year before Andersen's Enron related problems surfaced), or 2003 (the second year with the successor auditor). Further, exAndersen clients that followed the Andersen partner to the new audit firm had shorter audit report lags than ex-Andersen clients that did not follow their Andersen partner. Finally, clients with voluntary (i.e., non-Andersen) auditor changes have only marginally higher audit reporting lags compared to clients without auditor changes.

Some prior studies have examined the determinants and consequences associated with non-timely filings. Alford et al. (1993) provide descriptive evidence about the frequency of late $10-\mathrm{K}$ filings during the years 1978 to 1985 , and the financial characteristics of such firms. The evidence indicates that non-timely filers tend to be financially distressed.

Two recent studies examine the capital market costs of Form NT-10K filings (indicating non-timely filing of annual Form 10-K with the SEC). Bartov et al. (2008) find that there is a significant negative market reaction to the filing of a Form NT-10K, while Gao et al. (2011) show that there is a new trend of activist bondholders actively enforcing covenants related to technical defaults for firms that fail to file financial statements on time; such enforcement in turn leads to significant drops in stock and bond prices.

Wang et al. (2013) examine 11,024 firm-year observations during the years 2007 to 2010 and find that for accelerated filer firms, audit fees are, ceteris paribus, 26 (12) percent higher for those firms that had a Form NT-10K filing in the previous (current) 
year, after controlling for other measures of risk traditionally used in audit fee models, including the presence of material weaknesses in internal control.

\section{Audit Committees and Internal Control}

I now discuss prior research related to the association between audit committee characteristics and internal control, and the association between audit committees and audit risk. I first summarize research related to the association between audit committees and internal control reporting, and then discuss the association between audit committees and internal auditing. I then develop the arguments about the expected association between change in audit committee chair and the audit report lag.

DeZoort (1997) uses responses from 87 subjects to examine if experience has an effect on audit committee members' judgments. The experimental task required respondents to complete an internal control oversight judgments. The results indicate that audit committee members who have domain and task specific knowledge (that is, those that have prior experience in auditing and internal controls) made judgments similar to those made by external auditors in the evaluation of internal controls, in contrast to audit committee directors without such prior experience.

Krishnan (2005) examines the association between audit committee composition and internal control reporting. She first identified 128 companies that changed auditors between 1994 and 2000, and disclosed internal control problems in Form 8-Ks related to the auditor change; the matched control sample includes companies that changed auditors but did not have such internal control issues. She finds that such internal control problem disclosures are less likely if the audit committee of the client has a higher proportion of 
independent members; similarly, problem disclosures are less likely in the presence of financial experts on the audit committee.

The evidence in Krishnan (2005) is from the pre-SOX period; in addition, her sample only includes clients changing auditors. Recognizing the need for a broader sample, Krishnan and Viswanathan (2007) examine if the presence of financial experts on the audit committee is associated with (lack of) internal control weaknesses. These authors study 90 companies that reported internal control weaknesses between November 15, 2004 and March 1, 2005 and a control sample of companies in the same industry that did not report such internal control weaknesses. The results indicate that companies with internal control weaknesses were less likely to have financial experts on the audit committee. In a contemporaneous study, Zhang et al. (2007) identify 208 firms with material internal control problems disclosed pursuant to SOX 302 or 404 from November 15, 2004 to July 2005. The authors use a matched-sample of 208 firms without internal control weaknesses. The analyses indicate that firms with internal control problems are less likely to have experts (both accounting and non-accounting financial experts) on the audit committee.

Having an internal control problem is one issue. A somewhat related issue is the remediation of such problems, after the problems have been discovered. Goh (2009) examines if audit committee characteristics are associated with the timeliness of remediation of material weaknesses in internal control. He finds that firms with larger audit committees and greater proportion of non-accounting financial expertise take steps to remediate problems related to internal controls in a timelier manner. 
Naiker and Sharma (2009) examine the association between the presence of different types of former audit partners (affiliated or not) on the audit committee and the disclosure of internal control problems. These authors suggest that audit committee members who have been audit partners on the engagement in their previous roles (when with the audit firm) would be more effective monitors of internal control weaknesses compared to their counterparts without such experience. Using a sample of 1,225 firms that make SOX 404 disclosures for the 2004 fiscal year, the authors find the presence of such affiliated audit partners is associated with lower number of reported internal control deficiencies.

In summary, prior research shows that audit committee characteristics are important in the internal control reporting framework. Audit committee members can play a crucial role in effective monitoring of internal controls and financial reporting by maintaining constant communication with management, external auditors and internal auditors.

\section{Audit Committees and Interaction with Internal Auditing}

The Blue Ribbon Committee, referred to earlier, and others have noted that internal auditing is one important leg in the multi-legged table of corporate governance. Hence, to be effective, there must be regular, unfettered communication between the audit committee and internal auditing. Such communication can, in turn, lead to better monitoring by the audit committee. Internal auditing can be a natural friend of the audit committee - since both internal auditing and audit committee have important roles in the monitoring of internal controls and deterrence of fraud and errors. 
Scarbrough et al. (1998) conduct a survey of Canadian chief internal auditors to examine the interactions between audit committees and chief internal auditors. These authors examine the following issues related to the interaction of the audit committee with internal auditing: (1) the involvement of the audit committee in the hiring and firing of the chief internal auditor, (2) frequency and type of meetings between the audit committee and the chief internal auditor, and (3) audit committee review of the internal auditing program and results. The results show that the composition the audit committee has a significant influence on the interactions between the audit committee and the chief internal auditor. In a replication and extension of the Scarborough et al. (1998) study, Raghunandan et al. (2001) surveyed chief internal auditors of U.S. public companies. Raghunandan et al. (2001) find that audit committees that did not have inside or gray directors and had at least one member with accounting or finance expertise are more likely to (a) have longer meetings with the chief internal auditor, (b) provide access to the chief internal auditor and (c) review the internal audit program and review management's interaction with internal audit. Taken together, these two studies indicate that the composition of the audit committee has a significant influence on the committees' interaction with the chief internal auditor and, hence, on the quality of monitoring.

Barua et al. (2010) study the association between various audit committee characteristics and the internal audit budget using data from 181 firms. The results indicate that audit committees that had long-tenured members and had an auditing expert were associated with lower spending on internal auditing. These findings are interesting because they suggest that different types of monitoring can act as substitutes, instead of complements. The data in Barua et al. (2010) are from the pre-SOX period. Recognizing 
that the environment of governance changed significantly post-SOX, Abbott et al. (2010) examine the association between audit committee characteristics and the resources allocated to internal audit, based on a survey of 134 chief internal auditors from Fortune 1000 firms. Abbott et al. (2010) find that audit committees that have a greater oversight role over the internal audit function allocate a larger proportion of the internal audit hours towards internal controls.

Thus, prior studies have examined many issues related to the interaction between audit committees and internal auditing. Overall, the evidence from prior studies suggests that audit committee characteristics, such as the composition of the committee, are associated with the quality of the committee's interaction with internal auditing.

\section{Research Question}

The audit formula is: Audit Risk = Inherent Risk $x$ Control Risk $x$ Detection Risk (AICPA 1983). Auditing Standard [AS] No. 8 (PCAOB 2010) notes that the risk of material misstatement consists of inherent risk and control risk. Thus, if the risk of material misstatement (i.e., IR x CR) increases, the auditor will attempt to have a lower level of detection risk. AS No. 8 also notes that inherent risk and control risk "are related to the company, its environment, and its internal control."

Audit committees constitute an important element of the control environment of a company. Hence, when there is a change in the audit committee chair, it is likely that the auditor's assessment of the control environment will change. This in turn will lead to a change in the assessed risk of material misstatement and, hence, detection risk. AS No. 8 also notes that detection risk is "influenced by both the effectiveness of the substantive 
procedures and their application by the auditor." Hence, lower levels of detection risk require higher levels of effort by the auditor.

When there is a change in audit committee chair, the auditor is dealing with a new person in that role. Unfamiliar situations generally increase the perception of risk, so a new audit committee chair can be expected to be associated with a higher risk assessment by the external auditor. This, in turn, should lead to more audit work being performed after the fiscal year end when there is a change in audit committee chair-which, in turn, suggests that the audit report lag should be higher following a change in the audit committee chair.

Thus, the research question for the second part of the dissertation is:

RQ2: Is there an association between audit report lag and the change in audit committee chair?

Method

The following regression model is used to test the second research question:

SqrtLag $=\beta_{0}+\beta_{1} *$ ExtraOrdinary $+\beta_{2} *$ SqrtSeg $+\beta_{3} *$ Foreign $+\beta_{4} *$ HiGrowth

$+\beta_{5} *$ HiLitigation $+\beta_{6} *$ HiTech $+\beta_{7} *$ ZScore $+\beta_{8} *$ Loss $+\beta_{9} *$ GCOpinion

$$
+\beta_{10} * \operatorname{Ln}(\text { TotalAssets })+\beta_{11} * \text { ACCC }+\varepsilon
$$

$$
\begin{aligned}
\text { SqrtLag }= & \beta_{0}+\beta_{1} * \text { ExtraOrdinary }+\beta_{2} * \text { SqrtSeg }+\beta_{3} * \text { Foreign }+\beta_{4} * \text { HiGrowth } \\
& +\beta_{5} * \text { HiLitigation }+\beta_{6} * \text { HiTech }+\beta_{7} * \text { ZScore }+\beta_{8} * \text { Loss }+\beta_{9} * \text { GCOpinion } \\
& +\beta_{10} * \operatorname{Ln}(\text { TotalAssets })+\beta_{11} * \mathrm{BD}+\beta_{12} * \mathrm{NM}+\varepsilon
\end{aligned}
$$


In addition, the followings changes model regression model is also used test the second research question:

$\Delta$ SqrtLag $=\beta_{0}+\beta_{1} * \Delta$ ExtraOrdinary $+\beta_{2} * \Delta$ SqrtSeg $+\beta_{3} * \Delta$ Foreign $+\beta_{7} * \Delta$ ZScore

$+\beta_{8} * \Delta$ Loss $+\beta_{9} * \Delta$ GCOpinion $+\beta_{10} * \Delta \operatorname{Ln}$ (TotalAssets) $+\beta_{11} * \Delta$ ACCC $+\varepsilon$

The variables are defined as follows:

SqrtLaq $=$ Square root of the number of days between fiscal year-end and the date of the audit report;

ExtraOrdinary $=1$ if extraordinary items in the financial statements, 0 otherwise;

SqrtSeg $=$ Square root of the number of segments;

Foreign $=\mathrm{I}$ if company has foreign operations, 0 otherwise;

HiGrowth $=1$ if company is in high growth industry, 0 otherwise;

HiLitigation $=1$ if company is in high litigation industry; 0 otherwise;

HiTech = 1 if company is in high technology industry, 0 otherwise;

ZScore = Probability of bankruptcy using Zmijewski's model;

Loss $=1$ if company has a loss before extraordinary items, 0 otherwise;

GCOpinion $=1$ if the firm receives a going concern opinion, 0 otherwise;

$\operatorname{Ln}($ TotalAssets $)=$ Natural logarithm of total assets;

$\mathrm{ACCC}=1$ if there was a change in the Audit Committee Chair, 0 otherwise;

$\mathrm{BD}=1$ if new audit chair was previously a member of the board either in the audit committee or some other capacity, 0 otherwise;

$\mathrm{NM}=1$ if new audit chair was previously not a member of the board, 0 otherwise; 


$$
\Delta=2009 \text { data }-2007 \text { data }
$$

Sample

The sample to examine the second research question is similar to that used for the first research question. As before, I started with the 2009 Corporate Library Company Data file and have a sample of 1,832 companies for which director information was available. Note that for the second research question, there were 141 companies in which the z-score could not be calculated due to missing data. After deleting these and other observations due to missing values, the final sample is 1,618 companies for the audit report lag model.

Results

Descriptive Statistics

Table 4 provides the descriptive statistics for the variables used in the regression model. The mean audit report lag for the sample companies is 63.1 days while the median is 59 days. The mean and median of total assets are $\$ 512$ million and $\$ 77$ million, respectively. The distribution for total assets appears to be highly skewed, so consistent with prior research, the natural logarithm is used to transform total assets. About 21 percent of the companies reported extraordinary items in their financial statements. About one-third of the companies were in high-growth and high-tech industries, while 42 percent of the companies were in high litigation industries. About 40 percent of the companies reported a loss before extraordinary items. 


\section{Regression Results}

The regression results using Sqrt(Lag) as the dependent variable and ACCC as the variable of interest are presented in the first three columns of Table 5 (Model 3). The variables Loss, GCOpinion, and LN(TotalAssets) are significant $(\mathrm{p}<0.001)$ while other variables are not being significant including ACCC $(p=0.901)$. The model has an adjusted $\mathrm{R}^{2}$ of 25 percent, in line with those reported in other recent studies (e.g., Krishnan and Yang 2009; Tanyi et al. 2010).

The last three columns of Table 5 present the results for Model 4. In this regression $\operatorname{Sqrt}(\mathrm{Lag})$ is the dependent variable while $B D$, and $N M$ are the variables of interest; the inferences from this regression are substantively similar to those for Model 4.

Overall, the variables of interest (ACCC, $B D$, and $N M)$, which are the variables associated with the change in the audit committee chair are not significant $(p>.05)$. These results indicate that audit report lag is not associated with the change in the audit committee chair regardless of their membership in the audit committee or board prior to being made chair.

The regression results for the changes model are presented in Table 7 (Model 5). The coefficients of Extraordinary $(p=.031)$, ZScore $(p<.001)$, Loss $(p=0.001)$, and GCOpinion $(\mathrm{p}=.015)$ are significant. ACCC, the variable of interest, is marginally significant $(\mathrm{p}=.066)$.

The inferences from the regression model that has Sqrt(Lag) as a dependent variable and $\mathrm{BD}$ and $\mathrm{NM}$ as the variables of interest (in lieu of ACCC) are substantively similar to those presented for the model that has ACCC as the variable of interest. Neither of the two variables of interest is significant in the levels model. 


\section{Summary}

Audit report lag is defined as the number of days after fiscal year end for a company that the audited financial statements are filed with the SEC. There is a significant body of research investigating the determinants of audit report lag. However, prior literature has not examined the relationship between audit committee chair change and audit report lag. The second part of the dissertation examines the role that the change in the audit committee chair has on a company's audit report lag. This research is especially relevant given the responsibilities that the Sarbanes-Oxley Act has placed on audit committees in ensuring accurate and fairly presented financial statements that are sufficiently audited by an independent audit firm.

Using audit committee director data from the 2009 Corporate Library data, I did not significant correlation between the change in the audit committee chair and the audit report lag when using a levels model. However, when using the changes model for the audit report lag, I find some evidence that the change in audit committee chair is associated with a longer audit report lag. 


\section{AUDIT CHAIR CHANGE AND AUDIT QUALITY}

\section{Motivation}

The third part of the dissertation investigates the implications of audit committee chair change to audit quality. Audit quality is a subject of interest for a number of stakeholders with our capital markets including investors, regulators, financial statement

prepares, and the accounting profession. Audit quality can be measured a number of ways, but two of the most common metrics are restatements and abnormal accruals. Prior studies have found that restatements lead to significant losses to investors (GAO 2002; Dechow et al. 1996; Anderson \& Yohn 2002). Prior studies have also found economic benefits for firms lower discretionary accruals (Xie 2001) and higher cost of capital for firms with low accruals quality (Francis et al. 2005).

Prior studies have shown that audit quality is related to some characteristics of audit committees, such as their composition and diligence. The third part of the dissertation adds to the body of research on the association between audit committees and audit quality by examining the significance of the role played by the audit committee chair in ensuring high quality financial reporting.

\section{Background}

As noted in the earlier chapters, the long-held view of the SEC and legislators is that an effective audit committee is an important element in the corporate governance and financial reporting framework. In addition, both regulatory and legislative actions during the past two decades reflect the view that the composition of the audit committee can be 
expected to influence the quality of financial reporting. Hence, it is not surprising that many prior studies have sought to examine if indeed there is an association between different dimensions of audit committee composition and various proxies for financial reporting quality.

Financial reporting quality is a construct that can be operationalized in multiple ways. While there is no one single measure that best captures this construct, prior studies have used the following proxies for financial reporting quality: abnormal accruals, restatements, and SEC enforcement actions.

I begin with a discussion of studies that have examined the association between audit committee composition and the quality of accruals. I then briefly summarize research related to the association between audit committee composition and (a) restatements and (b) SEC enforcement actions. In addition, I also discuss some studies that have used other approaches, such as experiments and interviews, to examine the impact of various audit committee composition related measures on both actual and perceived quality of corporate financial reporting.

\section{Prior Research}

\section{Audit Committees and Accruals}

Many recent studies have examined if various audit committee composition related measures are associated with abnormal accruals. For example, Klein (2002) uses a sample of S\&P 500 firms and examines accruals for 1991-1993. She finds that in companies that did not have audit committees with solely independent directors, abnormal accruals are higher (when compared to companies with solely independent 
directors on the committee). Bedard et al. (2004) examine data from 1996 and use a matched sample design; they find that the presence of a financial expert is negatively associated with discretionary accruals. In addition, they also find that earnings management is lower in those companies that had audit committees comprised of independent members. Yang and Krishnan (2005) examine the association between earnings management and several audit committee characteristics, using data from 896 observations from the years 1996-2000. They find that the following audit committee director characteristics are associated with earnings management: number of outside directorships held by audit committee directors, extent of stock ownership, and average tenure of the audit committee directors.

While the above cited studies use data from the pre-SOX period, other studies have examined the post-SOX period. However, in such studies, the focus is on having different types of experts since variations in independence are less likely in the post-SOX period (given the requirements of SOX for audit committees to have solely independent directors). Dhaliwal et al. (2010) use a sample of 770 firms with available data during 2004-2006, and find that the presence of accounting experts on the audit is positively associated with accruals quality. Further, accruals quality is positively related to accounting experts who (a) are independent from the firm, (b) hold low levels of multiple directorships, and (c) have a lower tenure in their firms.

\section{Restatements}

The quality of financial reporting can also be measured by the number of restatements and internal control weakness disclosures. Abbott et al. (2004) examine 88 
firms with annual financial statement restatements and a control sample of firms matched by industry, size, auditor types and listing. They find that the likelihood of a restatement is lower for those firms where the audit committee is comprised of fully independent members and/or includes at least one financial expert. They also find that companies that had active audit committees had fewer restatements compared to the control group. Their findings echo the recommendations of the $\mathrm{BRC}$ and others who have argued for independent audit committees, presence of at least one member with financial expertise, and more audit committee meetings - all of which lead to effective monitoring by audit committees. Similarly, Agrawal and Chadha (2005) provide empirical evidence between audit committee composition and the likelihood of a misstatement. They examine 159 U.S. public companies that restated their earnings in 2000 or 2001 and identify a sample of 159 firms that did not restate (control group). They find that probability of a restatement is lower in companies where audit committees have independent directors with financial expertise.

Some audit committee directors serve on many boards and on many audit committees. This practice is called "busy boarding" and is frowned upon by activists and advocates of good-governance. While some argue that litigation and, perhaps more importantly, reputation-related concerns are sufficient to keep directors on their toes, opponents of "busy-boarding" argue that such practice stretches directors thin and hence lead to lower quality monitoring. Sharma and Iselin (2012) investigate the association between multiple-directorships of independent audit committee members and financial statement misstatements in the pre- and post-SOX periods. These authors find that there is a significant positive association between financial misstatements and multiple- 
directorships in the post-SOX environment, suggesting that independent audit committee members serving on multiple boards may be stretched too thinly to be effective in performing their monitoring responsibilities.

Another issue that has received attention from good governance advocates is director tenure. During the Enron hearings held by the U.S. Senate's Committee on Governmental Affairs (U.S. Senate 2002) one of the issues that was raised was whether the audit committee directors had been on the audit committee for too long, and hence were too close to management. While some argue that increased director tenure leads to better knowledge of the company and perhaps contribute to enhanced monitoring, others argue that too long a tenure leads a director to become complacent (Vafeas 2003). Sharma and Iselin (2012) also find that a significant positive association between audit committee director tenure and financial statement misstatements, suggesting that the quality of monitoring declines when the audit committee includes directors with long tenures.

\section{SEC Enforcement Actions}

McMullen and Raghunandan (1996) examine 51 companies with two types of financial reporting problems (SEC enforcement actions and material restatements of quarterly earnings) and compared them to those that did not have any financial reporting problems. The results indicate that companies that had problems did not have audit committees comprising solely of outside directors; in addition, problem companies were also more likely to have no CPAs on their audit committees compared to no problem companies. 
Abbott et al. (2000) examine 78 firms subject to SEC enforcement action and a control sample of 78 firms matched based on size, industry, time period and exchange. These authors find that SEC enforcement is less likely at firms with audit committees that both (a) have solely independent directors and (b) meet at least twice a year. Similarly, Beasley et al. (2000) examine financial statement frauds by 66 companies in three industries (technology, healthcare and financial services), along with a matched control sample of clean firms. The results show that independent and diligent audit committees are less likely in the fraud companies.

\section{Experimental Evidence}

Some studies have used experiments to examine the effect of having different types of audit committee directors on the quality of financial reporting. DeZoort and Salterio (2001) conduct an experiment using 68 Canadian audit committee directors. In the experiment, respondents were asked about a dispute between the auditor and management involving a material accounting issue. The results indicate that audit committee members who are independent and possess prior audit experience will be more likely to advocate a "substance" approach in the dispute, and more likely to support the auditor in the dispute with management. Krishnamoorthy et al. (2002) survey audit partners and managers about perceptions of financial reporting quality and audit committee effectiveness. Nearly half of the respondents replied that audit committee members did not possess the required financial knowledge to ensure high financial reporting quality. Many respondents expressed reservations about audit committee 
support for auditors in disagreements with management about the appropriate accounting treatment.

In summary, prior studies have examined many different time periods and samples to examine the association between the composition of audit committee members and the quality of financial reporting. The evidence from such studies indicates that audit committee member characteristics (as measured by level of independence, presence of experts, number of meetings, presence of an audit committee charter etc.) has an impact on the quality of financial reporting.

\section{Research Question}

As discussed in the above section, prior research related to audit committee composition has focused primarily on audit committee director independence and financial expertise. In addition, some studies have also examined other constructs such as audit committee director tenure and busyness.

The chair of the audit committee plays an important role in setting the overall tone of monitoring by the committee. The chair controls the agenda and, as such, has a significant influence over the functioning of the committee. Yet, there is little empirical evidence about the association between changes in the chair of the audit committee and the quality of financial reporting. Given the call by Carcello et al. (2011) for additional research related to the role of the audit committee chair, I examine the association between change in audit committee chair and financial reporting quality in the third part of my dissertation. 
RQ3: Is there an association between financial reporting quality and the change in audit committee chair?

Method

I first use the following regression models to examine the research question, with subsequent restatement of the financial statements as the dependent variable:

$$
\begin{aligned}
\text { Restatement }= & \beta_{0}+\beta_{1} * \operatorname{Ln}(\text { TotalAssets })+\beta_{2} * \text { ACExpert }+\beta_{3} * \text { Leverage } \\
& +\beta_{4} * \text { SpecialistAud }+\beta_{5} * \text { Raise }+\beta_{6} * \text { ACCC }+\varepsilon \\
\text { Restatement }= & \beta_{0}+\beta_{1} * \operatorname{Ln}(\text { TotalAssets })+\beta_{2} * \text { ACExpert }+\beta_{3} * \text { Leverage } \\
& +\beta_{4} * \text { SpecialistAud }+\beta_{5} * \text { Raise }+\beta_{6} * \mathrm{BD}+\beta_{7} * \mathrm{NM}+\varepsilon
\end{aligned}
$$

The variables are defined as follows:

$$
\begin{aligned}
\text { Restatement } & =1 \text { if restatement of financial reports, } 0 \text { otherwise; } \\
\text { Ln(TotalAssets) } & =\text { Natural logarithm of total assets; } \\
\text { ACExpert } & =1 \text { if audit committee has a financial expert, } 0 \text { otherwise; } \\
\text { Leverage }= & \text { Ratio of total liabilities to total assets; } \\
\text { SpecialistAud }= & 1 \text { if auditor is an industry specialist, } 0 \text { otherwise; } \\
\text { Raise }= & \text { Ratio of cash raised (stock plus debt) to total assets; } \\
\text { ACCC }= & 1 \text { if there was a change in the Audit Committee Chair, } 0 \text { otherwise; } \\
\text { BD }= & 1 \text { if new audit chair was previously a member of the board either in } \\
& \text { the audit committee or some other capacity, } 0 \text { otherwise; } \\
\mathrm{NM}= & 1 \text { if new audit chair was previously not a member of the board, } 0 \\
& \text { otherwise; }
\end{aligned}
$$


Next, I use the following regression models to examine the research question, with abnormal accruals as the dependent variable:

$$
\begin{aligned}
\text { absPMAA }= & \beta_{0}+\beta_{1} * \operatorname{Ln}(\text { TotalAssets })+\beta_{2} * \mathrm{BM}+\beta_{3} * \text { SGrowth }+\beta_{4} * \mathrm{ROA} \\
& +\beta_{5} * \mathrm{OCF}+\beta_{6} * \mathrm{DE}+\beta_{7} * \mathrm{OpCycle}+\beta_{8} * \mathrm{ACCC}+\varepsilon \\
\text { absPMAA }= & \beta_{0}+\beta_{1} * \operatorname{Ln}(\text { TotalAssets })+\beta_{2} * \mathrm{BM}+\beta_{3} * \mathrm{SGrowth}+\beta_{4} * \mathrm{ROA} \\
& +\beta_{5} * \mathrm{OCF}+\beta_{6} * \mathrm{DE}+\beta_{7} * \mathrm{OpCycle}+\beta_{8} * \mathrm{BD}+\beta_{9} * \mathrm{NM}+\varepsilon \\
\text { absPMAWCA }= & \beta_{0}+\beta_{1} * \operatorname{Ln}(\text { TotalAssets })+\beta_{2} * \mathrm{BM}+\beta_{3} * \mathrm{SGrowth}+\beta_{4} * \mathrm{ROA} \\
& +\beta_{5} * \mathrm{OCF}+\beta_{6} * \mathrm{DE}+\beta_{7} * \mathrm{OpCycle}+\beta_{8} * \mathrm{ACCC}+\varepsilon \\
\mathrm{absPMAWCA}= & \beta_{0}+\beta_{1} * \operatorname{Ln}(\text { TotalAssets })+\beta_{2} * \mathrm{BM}+\beta_{3} * \mathrm{SGrowth}+\beta_{4} * \mathrm{ROA} \\
& +\beta_{5} * \mathrm{OCF}+\beta_{6} * \mathrm{DE}+\beta_{7} * \mathrm{OpCycle}+\beta_{8} * \mathrm{BD}+\beta_{9} * \mathrm{NM}+\varepsilon
\end{aligned}
$$

The variables are defined as follows:

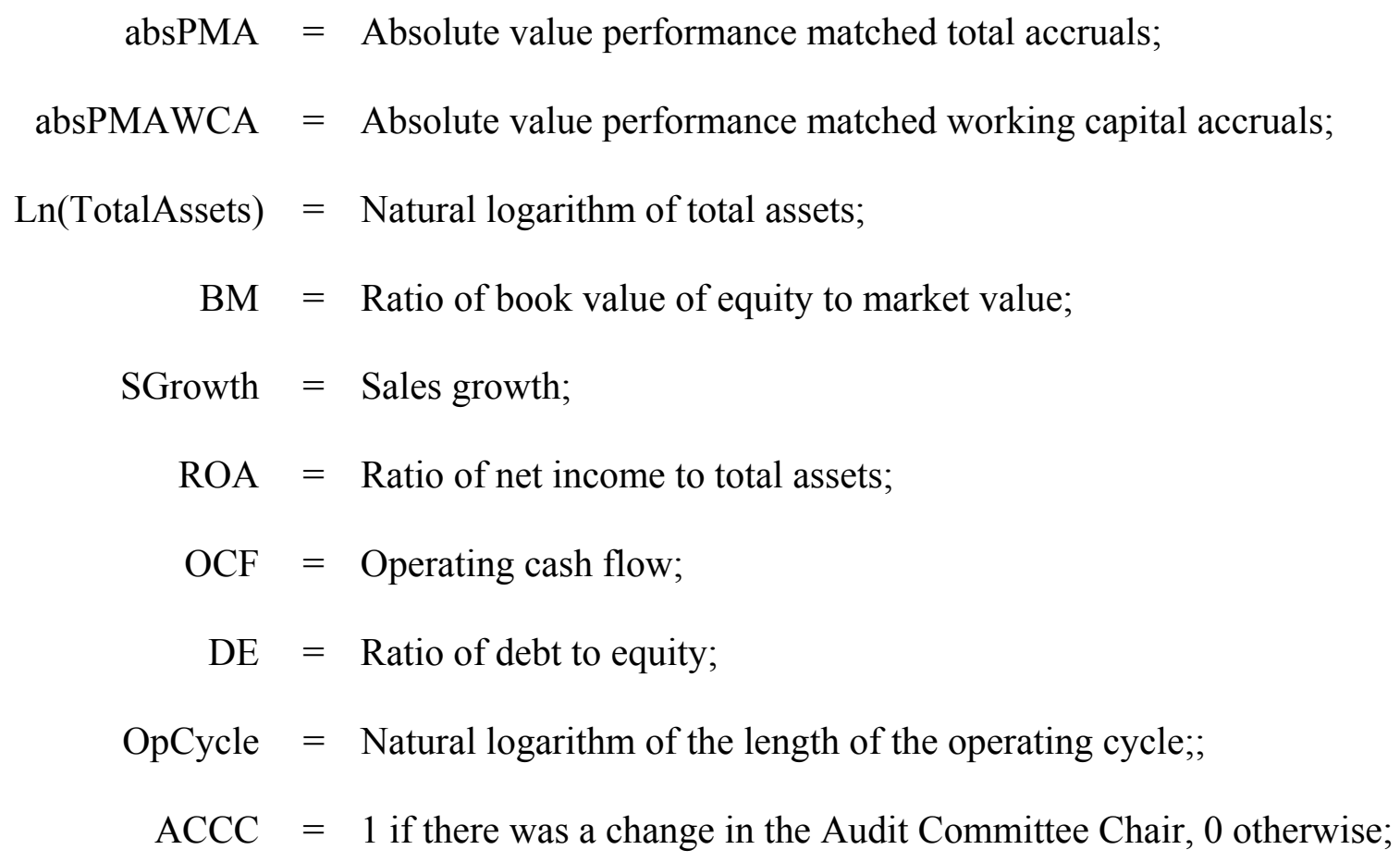




$$
\begin{aligned}
\mathrm{BD}= & 1 \text { if new audit chair was previously a member of the board either in } \\
& \text { the audit committee or some other capacity, } 0 \text { otherwise; } \\
\mathrm{NM}= & 1 \text { if new audit chair was previously not a member of the board, } 0 \\
& \text { otherwise; }
\end{aligned}
$$

Sample

The data collection for this part of the dissertation begins similar to the process used for the first two parts. Thus, I have of 1,832 companies for which Corporate Library director information was available. For the 1,832 companies, financial data was obtained from Compustat and audit related data was obtained from Audit Analytics. There were 70 companies with missing financial data resulting in a sample size of 1,762 companies. Due to missing data for values of the variables in the model, the final sample for the restatement analysis is 1,577 companies. Similarly, the sample sizes for the performance matched total accruals and the performance matched working capital accrual models are 1,414 and 1,397 , respectively.

Results

\section{Descriptive Statistics for Restatements Model}

Table 8 provides the descriptive statistics for the variables used in the regression model with restatements as the dependent variable. Ten percent of the sample has a subsequent restatement. The mean and median of total assets are $\$ 512$ million and $\$ 77$ million, respectively. ACExpert had a mean of 0.55 , meaning a little over one half of the sample had ta financial committee member that was a financial expert. SpecialistAud had 
a mean of 0.24 , which indicates that less than one fourth of the sample had an auditor that was an industry specialist.

\section{Regression Results}

The logistic regression results using Restatement as the dependent variable and $\mathrm{BD}$ and $\mathrm{NM}$ as the variables of interest are presented in the first three columns of Table 9 (Model 6, Model 7, and Model 8). Ln(Total Assets) was significant $(\mathrm{p}<.05)$ with a negative coefficient. None of the other control variables is significant at conventional levels.

Considering the variables of interest (BD and NM), which are the variables associated with the change in the audit committee chair, none is significant $(p>.05$ in each instance). These results indicate that subsequent restatements are not associated with the change in the audit committee chair regardless of their membership in the audit committee or board prior to being made chair.

\section{Abnormal Accruals Regressions}

The regression results for the models that have absPMAA (absolute value performance matched total accruals) and absPMAWCA (absolute value performance matched working capital accruals) as the dependent variable are presented in Table 11. The overall results of the regressions are significant $(\mathrm{p}=0.001)$, and the models have adjusted R-squares around 18 percent.

Most of the control variables in the two models are significant and have the expected coefficient signs. Contrary to expectations, the coefficient of ACCC (which is 
the variables associated with the change in the audit committee chair), has positive coefficient and is significant $(\mathrm{P}<.05)$ in both regressions. These results indicate that abnormal accruals (absolute value of performance matched accruals and absolute value of performance matched working capital accruals) are higher when an audit committee has a new chair.

Summary

Prior research has used restatements (publishing corrected financial statements after original submission) or discretionary accrual quality (abnormal accruals) to assess audit quality. A number or prior research have established a correlation between characteristics of audit committees and the possibility of restatements (Abbott et al. 2004 and Agrawal \& Chadha 2005) while others have shown that same correlation to abnormal accruals (Xie et al.2003, Bedard et al. 2004, Dhaliwl et al. 2006, and Carcello et al. 2008).

The objective of my research was to examine the association between audit committee chair change as the audit committee characteristic and two measures of audit quality: restatements and abnormal accruals. For the logistic regression model using restatements as the dependent variable, the results were not significant. The regression model for both the absolute value performance matched total accruals (absPMAA) and the absolute value performance matched working capital accrual are significant, but contrary to expectations audit quality appears to be lower when there is a change in audit committee chair. 


\section{CONCLUSION}

The role of the audit committee in a publicly traded company has continually evolved from its early beginning when the concept of an audit committee was encouraged by the SEC in 1940 as a result of the McKesson and Robbins case. Such a focus on the audit committee continued during the late 1990's when, through both actions and speeches, the former SEC Chairman called for greater audit committee independence. Subsequently, such focus on the audit committee was formally codified into law when the Sarbanes-Oxley Act was enacted in 2002.

Given such legislative and regulatory initiatives, there has been a spurt in empirical research related to audit committee composition. Specifically, prior studies have examined the effects of variations in audit committee composition on both the audit process and on various audit-related outcomes. A number of prior studies have examined characteristics such as financial expertise, gender, composition, age, number of meetings, and backgrounds of audit committee members. However, limited published literature exists that examines the role of the audit committee chair and the impact that that person has on the quality of the financial statement process.

My dissertation addresses this area of accounting research because the chair of the audit committee has an important role to play in setting the agenda for the committee and thus can influence the tone of the audit committee's monitoring activities. Thus, the impact that the audit committee chair has on the financial statement process is more significant than not only other board of directors but also other audit committee members. 
The first part of my dissertation examines the association between change in audit committee chair and audit fees. Using data for 61,331 directors across 3,417 companies using the Corporate Library database, I find that the change in audit committee chair is significantly related to audit fees. Specifically, audit fees are significantly higher when there is a change in audit committee chair. This correlation also holds when extra granularity is added and the new chair has not been on the board before becoming the audit committee chair and also when the new chair was previously a member of the board.

The second part of the dissertation examines the association between the change in the audit committee chair and audit report lag. The audit report lag was run with two different models: levels and changes. The first audit report lag model used a variable that just examined the change in the audit committee chair while the second model added an extra granularity by using two variables to look as the prior role of the new audit committee chair (not a member of the board, or member of the board). While the overall regression is significant, I find that there is no association between a change in audit committee chair and the audit report lag when using a levels model. However, when using a changes model, I find that the change in audit committee chair is associated with an increase in audit report lag.

The third part of the dissertation examines the change in audit committee chair to audit quality. Specifically, restatement and abnormal accruals are examined as a proxy for audit quality, which is consistent with prior research. In the restatements model, I find that none of the variables used for the audit committee chair change (BD and NM) is significant at conventional levels. In the abnormal accrual models, the change in the 
audit committee chair was found to be significant ( $p<0.01$ ), but the positive coefficients indicate that accruals are higher when there is a change in audit committee chair.

In summary, my dissertation examines an important issue that has significant public policy implications. Overall, I find that changes in audit committee chair have impact on the auditing process.

As in any empirical project, there are many limitations. First, I only examine one year in my analysis. Future research can examine additional years to see if the results are time dependent. Second, due to data collection related constraints, my analysis focuses on the largest companies. Future research can examine smaller companies, and examine if the results differ for smaller companies that are subject to lower levels of monitoring by the analysts and the media. 
Table 1

\section{Sample Selection}

2009 Corporate Library Company Data File

3,417

Less:

Foreign companies

Fiscal year-end not 12/31 (12/25-1/6)

Financial, insurance, and real estate companies

US Companies with FYE of 12/31 excluding Fin, Ins, RE Co.

$\underline{1,585}$

1,832

2009 Directors that were audit committee chairs

1,832

Less:

Audit chairs in 2009 that were also audit chairs in 2008

$(1,493)$

Audit chairs in 2009 that were not audit chairs in 2008

Audit Committee Chairs in 2009 that were not Audit chairs in 2008

Audit chairs in 2009 but were not on the board in 2008

194

Audit chairs in 2009 that were on the board but not members of the audit committee in 2008

Audit chairs in 3009 that were audit committee members in 2008

$\underline{118}$

Audit committee chairs in 2009 that were not audit chairs in 2008

$\frac{118}{339}$ 
Table 2

Descriptive Statistics for the Audit Fee Models

$\underline{\text { Variable }}$

Ln(AuditFees)

Ln(TotalAssets)

InvRecTA

Foreign

SqrtSeg

CurrentRatio

Loss

Leverage

Big4

GCOpinion

Initial

ICW

ACCC

$\mathrm{BD}$

NM

\begin{tabular}{|c|c|c|c|c|}
\hline$\underline{\text { Mean }}$ & $\underline{\text { Std.Dev. }}$ & $\frac{25 \text { th }}{\text { percentile }}$ & $\underline{\text { Median }}$ & $\frac{75 \text { th }}{\text { percentile }}$ \\
\hline 14.15 & 1.04 & 13.45 & 14.08 & 14.77 \\
\hline 18.30 & 1.80 & 16.98 & 18.16 & 19.52 \\
\hline 0.21 & 0.17 & 0.07 & 0.17 & 0.30 \\
\hline 0.55 & 0.50 & 0.00 & 1.00 & 1.00 \\
\hline 1.41 & 0.51 & 1.00 & 1.00 & 1.73 \\
\hline 2.56 & 2.52 & 1.13 & 1.81 & 2.97 \\
\hline 0.38 & 0.49 & 0.00 & 0.00 & 1.00 \\
\hline 0.59 & 0.42 & 0.35 & 0.56 & 0.74 \\
\hline 0.85 & 0.36 & 1.00 & 1.00 & 1.00 \\
\hline 0.05 & 0.21 & 0.00 & 0.00 & 0.00 \\
\hline 0.05 & 0.21 & 0.00 & 0.00 & 0.00 \\
\hline 0.03 & 0.17 & 0.00 & 0.00 & 0.00 \\
\hline 0.19 & 0.39 & 0.00 & 0.00 & 0.00 \\
\hline 0.08 & 0.27 & 0.00 & 0.00 & 0.00 \\
\hline 0.11 & 0.31 & 0.00 & 0.00 & 0.00 \\
\hline
\end{tabular}

The variables are defined as follows:

$\operatorname{Ln}($ AuditFees $)=$ Natural logarithm of audit fees;

$\operatorname{Ln}($ TotalAssets $)=$ Natural logarithm of total assets;

InvRecTA $=$ Inventory plus accounts receivable as a proportion of total assets;

Foreign $=$ I if company has foreign operations, 0 otherwise;

SqrtSeg $=$ Square root of the number of segments;

CurrentRatio $=$ Ratio of current assets to current liabilities;

Loss $=1$ if company has a loss before extraordinary items, 0 otherwise;

Leverage $=$ Ratio of total liabilities to total assets;

Big4 = 1 if the auditor is a Big 4 audit firm, 0 otherwise; 
GCOpinion $=1$ if the firm receives a going concern opinion, 0 otherwise;

Initial $=1$ if the audit engagement is the first year audit, 0 otherwise;

$\mathrm{ICW}=1$ if the firm has a material internal control weakness (disclosed pursuant to SOX 404), 0 otherwise;

$\mathrm{ACCC}=1$ if there was a change in the Audit Committee Chair, 0 otherwise;

$\mathrm{BD}=1$ if new audit chair was previously a member of the board either in the audit committee or some other capacity, 0 otherwise;

$\mathrm{NM}=1$ if new audit chair was previously not a member of the board, 0 otherwise; 
Table 3

Regression Results for the Audit Fee Models

Model 1:

$$
\begin{aligned}
\text { Ln(AuditFees })= & \beta_{0}+\beta_{1} * \operatorname{Ln}(\text { TotalAssets })+\beta_{2} * \text { InvRecTA }+\beta_{3} * \text { Foreign }+\beta_{4} * \text { SqrtSeg } \\
& +\beta_{5} * \text { CurrentRatio }+\beta_{6} * \text { Loss }+\beta_{7} * \text { Leverage }+\beta_{8} * \text { Big } 4 \\
& +\beta_{9} * \text { GCOpinion }+\beta_{10} * \text { Initial }+\beta_{11} * \text { ICW }+\beta_{12} * A C C+\varepsilon
\end{aligned}
$$

Model 2:

$$
\begin{aligned}
\text { Ln(AuditFees })= & \beta_{0}+\beta_{1} * \operatorname{Ln}(\text { TotalAssets })+\beta_{2} * \text { InvRecTA }+\beta_{3} * \text { Foreign }+\beta_{4} * \text { SqrtSeg } \\
& +\beta_{5} * \text { CurrentRatio }+\beta_{6} * \text { Loss }+\beta_{7} * \text { Leverage }+\beta_{8} * \text { Big } 4 \\
& +\beta_{9} * \text { GCOpinion }+\beta_{10} * \text { Initial }+\beta_{11} * \text { ICW }+\beta_{12} * \text { BD }+\beta_{13} * \mathrm{NM}+\varepsilon
\end{aligned}
$$

Variable
Intercept
Ln(TotalAssets)
InvRecTA
Foreign
SqrtSeg
CurrentRatio
Loss
Leverage
Big4
GCOpinion
Initial
ICW
ACCC
BD
NM

Model 1 $\underline{\text { Coefficient }}$

\begin{tabular}{|c|c|c|}
\hline 5.68 & 34.01 & $<0.001$ \\
\hline 0.408 & 44.76 & $<0.001$ \\
\hline 0.352 & 4.43 & $<0.001$ \\
\hline 0.493 & 17.89 & $<0.001$ \\
\hline 0.142 & 5.29 & $<0.001$ \\
\hline 0.004 & 0.75 & 0.456 \\
\hline 0.063 & 2.26 & 0.024 \\
\hline 0.190 & 5.41 & $<0.001$ \\
\hline 0.331 & 8.58 & $<0.001$ \\
\hline 0.069 & 1.02 & 0.306 \\
\hline 0.007 & 0.11 & 0.913 \\
\hline 0.403 & 5.30 & $<0.001$ \\
\hline 0.132 & 2.79 & 0.005 \\
\hline 0.080 & 1.87 & 0.061 \\
\hline
\end{tabular}

T-statistic

5.667
0.408
0.355
0.495
0.144
0.004
0.062
0.189
0.334
0.069
0.009
0.401
0.103

$\mathrm{n}$
Adjusted $\mathrm{R}^{2}=0.741$

Model 2

$\underline{\text { Coefficient }} \underline{\text { T-statistic }} \underline{\text { P-value }}$

Note: P-values are tailed. Variables are defined in Table 2. 
Table 4

Descriptive Statistics for the Audit Report Lag Models

\begin{tabular}{|c|c|c|c|c|c|}
\hline Variable & Mean & $\underline{\text { Std.Dev. }}$ & $\frac{25 \text { th }}{\text { percentile }}$ & Median & percentile \\
\hline SqrtLag & 7.88 & 0.93 & 7.48 & 7.68 & 8.43 \\
\hline Extraordinary & 0.21 & 0.41 & 0.00 & 0.00 & 0.00 \\
\hline SqrtSeg & 1.42 & 0.51 & 1.00 & 1.00 & 1.73 \\
\hline Foreign & 0.55 & 0.50 & 0.00 & 1.00 & 1.00 \\
\hline HiGrowth & 0.33 & 0.50 & 0.00 & 0.00 & 1.00 \\
\hline HiLitigation & 0.42 & 0.49 & 0.00 & 0.00 & 1.00 \\
\hline HiTech & 0.31 & 0.46 & 0.00 & 0.00 & 1.00 \\
\hline ZScore & -1.85 & 3.06 & -3.31 & -2.12 & -1.01 \\
\hline Loss & 0.40 & 0.49 & 0.00 & 0.00 & 1.00 \\
\hline GCOpinion & 0.04 & 0.19 & 0.00 & 0.00 & 1.00 \\
\hline Ln(TotalAssets) & 18.34 & 1.81 & 17.01 & 18.21 & 19.54 \\
\hline $\mathrm{ACCC}$ & 0.19 & 0.39 & 0.00 & 0.00 & 0.00 \\
\hline $\mathrm{BD}$ & 0.08 & 0.27 & 0.00 & 0.00 & 0.00 \\
\hline NM & 0.11 & 0.31 & 0.00 & 0.00 & 0.00 \\
\hline
\end{tabular}

The variables are defined as follows:

SqrtLaq $=$ Square root of the number of days between fiscal year-end and the date of the audit report;

ExtraOrdinary $=1$ if extraordinary items in the financial statements, 0 otherwise;

SqrtSeg $=$ Square root of the number of segments;

Foreign $=\mathrm{I}$ if company has foreign operations, 0 otherwise;

HiGrowth $=1$ if company is in high growth industry, 0 otherwise;

HiLitigation $=1$ if company is in high litigation industry; 0 otherwise;

HiTech = 1 if company is in high technology industry, 0 otherwise;

ZScore = Probability of bankruptcy using Zmijewski's model; 


$$
\begin{aligned}
& \text { Loss }=1 \text { if company has a loss before extraordinary items, } 0 \text { otherwise; } \\
& \text { GCOpinion }= 1 \text { if the firm receives a going concern opinion, } 0 \text { otherwise; } \\
&\text { Ln(TotalAssets })=\text { Natural logarithm of total assets; } \\
& \text { ACCC }=1 \text { if there was a change in the Audit Committee Chair, } 0 \text { otherwise; } \\
& \text { BD }=1 \text { if new audit chair was previously a member of the board either in } \\
& \text { NM }=1 \text { if new audit chair was previously not a member of the board, } 0 \\
& \quad \text { otherwise; }
\end{aligned}
$$


Table 5

Regression Results for the Audit Report Lag Models

Model 3:

SqrtLag $=\beta_{0}+\beta_{1} *$ ExtraOrdinary $+\beta_{2} *$ SqrtSeg $+\beta_{3} *$ Foreign $+\beta_{4} *$ HiGrowth

$+\beta_{5} *$ HiLitigation $+\beta 6_{6} *$ HiTech $+\beta_{7} *$ ZScore $+\beta_{8} *$ Loss $+\beta{ }_{9} *$ GCOpinion

$+\beta_{10} * \operatorname{Ln}$ (TotalAssets) $+\beta_{11} *$ ACCC $+\varepsilon$

Model 4:

SqrtLag $=\beta_{0}+\beta_{1} *$ ExtraOrdinary $+\beta_{2} *$ SqrtSeg $+\beta_{3} *$ Foreign $+\beta_{4} *$ HiGrowth

$+\beta 5^{*}$ HiLitigation $+\beta 6_{6} *$ HiTech $+\beta_{7} *$ ZScore $+\beta_{8} *$ Loss $+\beta{ }^{*}$ GCOpinion

$+\beta_{10} * \operatorname{Ln}$ (TotalAssets) $+\beta_{11} * \mathrm{BD}+\beta_{12} * \mathrm{NM}+\varepsilon$

$\underline{\text { Variable }}$

Intercept

Extraordinary

SqrtSeg

Foreign

HiGrowth

HiLitigation

HiTech

ZScore

Loss

GCOpinion

Ln(TotalAssets)

ACCC

$\mathrm{BD}$

NM
Model 3

$\underline{\text { Coefficient }}$

11.251

0.081

0.049

0.088

0.105

$-0.109$

$-0.080$

$-0.009$

0.244

1.172

$-0.197$

$-0.006$
T-statistic p-value

$46.98<0.001$

1.67

1.20

2.02

2.39

$-1.81$

$-1.29$

$-1.39$

5.57

10.90

$-15.21$

$-0.12$

0.095

0.229

0.044

0.017

0.071

0.197

0.165

$<0.001$

$<0.001$

$<0.001$

0.901
Model 4

$\underline{\text { Coefficient }} \underline{\text { T-statistic }} \underline{\text { P-value }}$

\begin{tabular}{rrrr}
\cline { 1 - 1 } Coefficient & & T-statistic & P-value \\
11.197 & 46.36 & $<0.001$ \\
0.080 & 1.64 & 0.100 \\
0.053 & 1.29 & 0.199 \\
0.090 & 2.08 & 0.038 \\
0.102 & 2.33 & 0.020 \\
-0.105 & -1.74 & 0.081 \\
-0.080 & -1.29 & 0.198 \\
-0.010 & -1.40 & 0.162 \\
0.240 & 5.48 & $<0.001$ \\
1.173 & 10.91 & $<0.001$ \\
-0.195 & -14.90 & $<0.001$ \\
& & \\
-0.078 & -1.08 & 0.279 \\
0.050 & 0.78 & 0.434 \\
---------------------------------- \\
& $\mathrm{n}=1,618$ \\
& Adjusted R ${ }^{2}=0.250$
\end{tabular}

Adjusted $\mathrm{R}^{2}=0.250$

$\mathrm{n}=1,618$

Adjusted $\mathrm{R}^{2}=0.250$
Note: P-values are tailed. Variables are defined in Table 4.

Model 3 final sample size: 1,618 companies

Model 4 final sample size: 1,618 companies 
Table 6

Descriptive Statistics for the Audit Report Lag Changes Model

$\begin{array}{lrrrrrr}\text { Variable } & \text { Mean } & \underline{\text { Std.Dev. }} & \text { percentile } & & \text { Median } & \text { percentile } \\ & & & & & \\ \Delta \text { SqrtLag } & -0.14 & 0.91 & -0.30 & -0.12 & 0.12 \\ \Delta \text { Extraordinary } & -0.04 & 0.42 & 0.00 & 0.00 & 0.00 \\ \Delta \text { SqrtSeg } & -0.08 & 0.41 & 0.00 & 0.00 & 0.00 \\ \Delta \text { Foreign } & 0.03 & 0.26 & 0.00 & 0.00 & 0.00 \\ \Delta \text { HiGrowth } & 0.00 & 0.00 & 0.00 & 0.00 & 0.00 \\ \Delta \text { HiLitigation } & 0.00 & 0.00 & 0.00 & 0.00 & 0.00 \\ \Delta \text { HiTech } & 0.00 & 0.00 & 0.00 & 0.00 & 0.00 \\ \Delta \text { ZScore } & 0.18 & 6.21 & -0.33 & 0.10 & 0.69 \\ \Delta \text { Loss } & 0.12 & 0.49 & 0.00 & 0.00 & 0.00 \\ \Delta \text { GCOpinion } & 0.02 & 0.16 & 0.00 & 0.00 & 0.00 \\ \Delta \text { Ln(TotalAssets) } & -0.01 & 0.44 & -0.20 & 0.02 & 0.18 \\ \Delta \text { ACCC } & 0.02 & 0.54 & 0.00 & 0.00 & 0.00\end{array}$

The variables are defined as follows:

$\Delta$ SqrtLaq $=$ Square root of the number of days between fiscal year-end and the date of the audit report;

$\Delta$ ExtraOrdinary $=1$ if extraordinary items in the financial statements, 0 otherwise;

$\Delta$ SqrtSeg $=$ Square root of the number of segments;

$\Delta$ Foreign $=\mathrm{I}$ if company has foreign operations, 0 otherwise;

$\Delta$ HiGrowth $=1$ if company is in high growth industry, 0 otherwise;

$\Delta$ HiLitigation $=1$ if company is in high litigation industry; 0 otherwise;

$\Delta$ HiTech $=1$ if company is in high technology industry, 0 otherwise;

$\Delta$ ZScore $=$ Probability of bankruptcy using Zmijewski's model; 
$\Delta$ Loss $=1$ if company has a loss before extraordinary items, 0 otherwise; $\Delta$ GCOpinion $=1$ if the firm receives a going concern opinion, 0 otherwise;

\section{$\Delta \operatorname{Ln}($ TotalAssets $)=$ Natural logarithm of total assets;}

$\triangle \mathrm{ACCC}=1$ if there was a change in the Audit Committee Chair, 0 otherwise; 
Table 7

Regression Results for the Audit Report Lag Changes Model

Model 5:

$\begin{aligned} \Delta \text { SqrtLag }= & \beta_{0}+\beta_{1} * \Delta \text { ExtraOrdinary }+\beta_{2} * \Delta \text { SqrtSeg }+\beta_{3} * \Delta \text { Foreign }+\beta_{4} * \Delta \text { ZScore } \\ & +\beta_{5} * \Delta \text { Loss }+\beta 6^{*} \Delta \text { GCOpinion }+\beta_{7} * \Delta \operatorname{Ln}(\text { TotalAssets })+\beta 8^{*} \Delta \text { ACCC }+\varepsilon\end{aligned}$

$\underline{\text { Variable }}$

Intercept

$\Delta$ Extraordinary

$\Delta$ SqrtSeg

$\Delta$ Foreign

$\Delta$ Zscore

$\Delta$ Loss

$\triangle$ GCOpinion

$\Delta \mathrm{Ln}$ (TotalAssets)

$\triangle \mathrm{ACCC}$

\begin{tabular}{|c|c|c|}
\hline Coefficient & T-statistic & p-value \\
\hline-0.173 & -7.37 & $<0.001$ \\
\hline-0.115 & -2.16 & 0.031 \\
\hline 0.001 & 0.02 & 0.983 \\
\hline-0.073 & -0.86 & 0.387 \\
\hline-0.192 & 7.50 & $<0.001$ \\
\hline 0.313 & 3.43 & 0.001 \\
\hline 0.333 & 2.44 & 0.015 \\
\hline 0.061 & 1.15 & 0.248 \\
\hline-0.075 & -1.84 & 0.066 \\
\hline & Adju & $\begin{array}{l}=1,636 \\
=0.047\end{array}$ \\
\hline
\end{tabular}

Note: P-values are tailed. Variables are defined in Table 6. 
Table 8

Descriptive Statistics for the Restatement Models

$\underline{\text { Variable }}$

Restatement

Ln(TotalAssets)

ACExpert

Leverage

SpecialistAud

Raise

ACCC

$\mathrm{BD}$

NM

\begin{tabular}{|c|c|c|c|c|}
\hline Mean & Std.Dev. & $\underline{25 \text { th }}$ & $\underline{\text { Median }}$ & $\underline{\text { percentile }}$ \\
\hline 0.10 & 0.29 & 0.00 & 0.00 & 0.00 \\
\hline 18.41 & 1.80 & 17.13 & 18.26 & 19.63 \\
\hline 0.55 & 0.50 & 0.00 & 1.00 & 1.00 \\
\hline 0.60 & 0.42 & 0.37 & 0.57 & 0.74 \\
\hline 0.24 & 0.43 & 0.00 & 0.00 & 0.00 \\
\hline 9.46 & 503.54 & -50.20 & -1.04 & 27.44 \\
\hline 0.13 & 0.33 & 0.00 & 0.00 & 0.00 \\
\hline 0.09 & 0.28 & 0.00 & 0.00 & 0.00 \\
\hline 0.04 & 0.19 & 0.00 & 0.00 & 0.00 \\
\hline
\end{tabular}

The variables are defined as follows:

Restatement $=1$ if restatement of financial reports, 0 otherwise;

Ln(TotalAssets $)=$ Natural logarithm of total assets;

ACExpert $=1$ if audit committee has a financial expert, 0 otherwise;

Leverage $=$ Ratio of total liabilities to total assets;

SpecialistAud = 1 if auditor is an industry specialist, 0 otherwise;

Raise $=$ Ratio of cash raised (stock plus debt) to total assets;

$\mathrm{ACCC}=1$ if there was a change in the Audit Committee Chair, 0 otherwise;

$\mathrm{BD}=1$ if new audit chair was previously a member of the board either in the audit committee or some other capacity, 0 otherwise;

$\mathrm{NM}=1$ if new audit chair was previously not a member of the board, 0 otherwise; 
Table 9

Logistic Regression Results for the Restatement Models

Model 6:

Restatement $=\beta_{0}+\beta_{1} * \operatorname{Ln}($ TotalAssets $)+\beta_{2} *$ ACExpert $+\beta_{3} *$ Leverage + $\beta_{4} *$ SpecialistAud $+\beta_{5} *$ Raise $+\beta_{6} *$ ACCC $+\varepsilon$

Model 7:

Restatement $=\beta_{0}+\beta_{1} * \operatorname{Ln}($ TotalAssets $)+\beta_{2} *$ ACExpert $+\beta_{3} *$ Leverage + $\beta_{4} *$ SpecialistAud $+\beta_{5} *$ Raise $+\beta_{6} * \mathrm{BD}+\beta_{7} * \mathrm{NM}+\varepsilon$

\begin{tabular}{|c|c|c|c|c|c|c|}
\hline \multirow[b]{2}{*}{ Variable } & \multicolumn{3}{|c|}{ 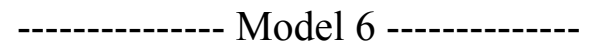 } & \multicolumn{3}{|c|}{--------------- Model 7 ------. } \\
\hline & $\underline{\text { Coefficient }}$ & Chi-square & p-value & Coefficient & Chi-square & $\mathrm{p}$-value \\
\hline Intercept & -0.06 & 0.00 & 0.95 & -0.02 & 0.00 & 0.98 \\
\hline Ln(TotalAssets) & -0.12 & 5.38 & 0.02 & -0.13 & 5.52 & 0.02 \\
\hline ACExpert & 0.18 & 0.93 & 0.34 & 0.17 & 0.89 & 0.35 \\
\hline Leverage & 0.12 & 0.47 & 0.49 & 0.12 & 0.49 & 0.49 \\
\hline SpecialistAud & -0.29 & 1.69 & 0.19 & -0.29 & 1.64 & 0.20 \\
\hline Raise & 0.00 & 1.75 & 0.19 & 0.00 & 1.81 & 0.18 \\
\hline ACCC & -0.39 & 1.84 & 0.17 & & & \\
\hline $\mathrm{BD}$ & & & & -0.39 & 1.32 & 0.25 \\
\hline NM & & & & -0.37 & 0.60 & 0.44 \\
\hline & & $\begin{array}{r}\text { Chi,sq. }=8.8 \\
\text { Pseudo R }\end{array}$ & $\begin{array}{l}=1,577 \\
p=.21 \\
=0.008\end{array}$ & & $\begin{array}{r}\text { Chi-sq. }=8 . \\
\text { Pseudo }\end{array}$ & $\begin{array}{l}=1,577 \\
, p=.26 \\
2=0.008\end{array}$ \\
\hline
\end{tabular}

Note: Variables are defined in Table 8. 
Table 10

Descriptive Statistics for the Performance Matched Accruals Models

$\begin{array}{lrrrrrr}\text { Variable } & \text { Mean } & \underline{\text { Std.Dev. }} & \text { percentile } & & \text { Median } & \begin{array}{r}\text { percentile } \\ \text { absPMAA }\end{array} \\ \text { absPMAWCA } & 0.08 & 0.10 & 0.02 & 0.05 & 0.09 \\ \text { Ln(TotalAssets) } & 0.07 & 0.10 & 0.02 & 0.04 & 0.09 \\ \text { BM } & 6.93 & 1.81 & 5.60 & 6.77 & 8.18 \\ \text { SGrowth } & 0.71 & 1.30 & 0.34 & 0.63 & 1.05 \\ \text { ROA } & 0.12 & 0.36 & -0.02 & 0.07 & 0.19 \\ \text { OCF } & -0.08 & 0.28 & -0.10 & 0.03 & 0.07 \\ \text { DE } & 3.44 & 12.95 & 0.00 & 0.50 & 2.12 \\ \text { OpCycle } & 1.77 & 6.76 & 0.41 & 1.05 & 2.23 \\ \text { ACCC } & 3.44 & 0.99 & 3.99 & 4.46 & 4.91 \\ \text { BD } & 0.16 & 0.36 & 0.00 & 0.00 & 0.00 \\ \text { NM } & 0.09 & 0.28 & 0.00 & 0.00 & 0.00 \\ & 0.07 & 0.25 & 0.00 & 0.00 & 0.00\end{array}$

Table 10 provides descriptive evidence about the variables used for the abnormal accruals analysis. The mean and median values of both of the abnormal accrual measures are in line with those reported in prior studies. The variables are defined as follows:

$$
\begin{aligned}
\text { absPMA } & =\text { Absolute value performance matched total accruals; } \\
\text { absPMAWCA } & =\text { Absolute value performance matched working capital accruals; } \\
\text { Ln(TotalAssets) } & =\text { Natural logarithm of total assets; } \\
\text { BM } & =\text { Ratio of book value of equity to market value; } \\
\text { SGrowth } & =\text { Sales growth; } \\
\text { ROA } & =\text { Ratio of net income to total assets; } \\
\text { OCF } & =\text { Operating cash flow; } \\
\text { DE } & =\text { Ratio of debt to equity; } \\
\text { OpCycle } & =\text { Natural logarithm of the length of the operating cycle; } \\
\text { ACCC } & =1 \text { if there was a change in the Audit Committee Chair, } 0 \text { otherwise; }
\end{aligned}
$$


$\mathrm{BD}=1$ if new audit chair was previously a member of the board either in the audit committee or some other capacity, 0 otherwise;

$\mathrm{NM}=1$ if new audit chair was previously not a member of the board, 0 otherwise; 
Table 11

Regression Results for Performance Matched Total Accruals Models

Model 8:

$\begin{aligned} \text { absPMAA }= & \beta_{0}+\beta_{1} * \operatorname{Ln}(\text { TotalAssets })+\beta_{2} * \mathrm{BM}+\beta_{3} * \text { SGrowth }+\beta_{4} * \text { ROA } \\ & +\beta_{5} * \text { OCF }+\beta_{6} * \text { DE }+\beta_{7} * \text { OpCycle }+\beta_{8} * \text { ACCC }+\varepsilon\end{aligned}$

Model 9:

$\begin{aligned} \text { absPMAA }= & \beta_{0}+\beta_{1} * \operatorname{Ln}(\text { TotalAssets })+\beta_{2} * \mathrm{BM}+\beta_{3} * \text { SGrowth }+\beta_{4} * \mathrm{ROA} \\ & +\beta_{5} * \mathrm{OCF}+\beta_{6} * \mathrm{DE}+\beta_{7} * \text { OpCycle }+\beta_{8} * \mathrm{BD}+\beta_{9} * \mathrm{NM}+\varepsilon\end{aligned}$

$\underline{\text { Variable }}$

Model 8

Coefficient

Intercept

Ln(TotalAssets)

$\mathrm{BM}$

SGrowth

ROA

$\mathrm{OCF}$

$\mathrm{DE}$

OpCycle

ACCC

$\mathrm{BD}$

NM

$\begin{array}{rrr}0.090 & 6.11 & <0.001 \\ -0.007 & -4.76 & <0.001 \\ -0.002 & -1.01 & 0.315 \\ 0.042 & 6.42 & <0.001 \\ -0.111 & -12.00 & <0.001 \\ 0.000 & 1.46 & 0.143 \\ 0.000 & 2.13 & 0.033 \\ 0.003 & 1.41 & 0.159 \\ 0.019 & 3.02 & 0.003\end{array}$

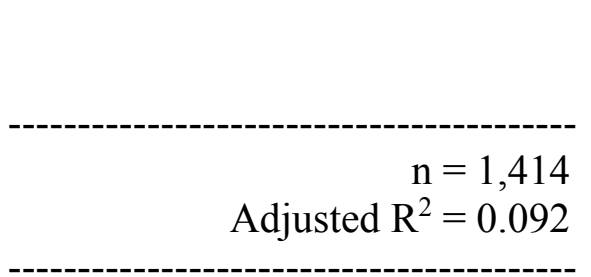

Model 9

$\underline{\text { Coefficient }} \underline{\text { T-statistic }} \underline{\text { P-value }}$

\begin{tabular}{|c|c|c|}
\hline 0.087 & 5.87 & $<0.001$ \\
\hline-0.006 & -4.51 & $<0.001$ \\
\hline-0.002 & -0.98 & 0.329 \\
\hline 0.041 & 6.28 & $<0.001$ \\
\hline-0.111 & -12.02 & $<0.001$ \\
\hline 0.000 & 1.49 & 0.136 \\
\hline 0.000 & 2.17 & 0.030 \\
\hline 0.004 & 1.49 & 0.136 \\
\hline 0.009 & 1.13 & 0.259 \\
\hline 0.032 & 3.48 & 0.001 \\
\hline
\end{tabular}

Note: P-values are two-tailed. Variables are defined in Table 10. 
Table 12

Regression Results for Performance Matched Working Capital Accruals Models

Model 10:

absPMAWCA $=\beta_{0}+\beta_{1} * \operatorname{Ln}($ TotalAssets $)+\beta_{2} * \mathrm{BM}+\beta_{3} *$ SGrowth $+\beta_{4} *$ ROA $+\beta_{5} * \mathrm{OCF}+\beta_{6} * \mathrm{DE}+\beta_{7} * \mathrm{OpCycle}+\beta_{8} * \mathrm{ACCC}+\varepsilon$

Model 11:

absPMAWCA $=\beta_{0}+\beta_{1} * \operatorname{Ln}$ (TotalAssets) $+\beta_{2} * \mathrm{BM}+\beta_{3} *$ SGrowth $+\beta_{4} *$ ROA

$+\beta{ }_{5} * \mathrm{OCF}+\beta_{6} * \mathrm{DE}+\beta_{7} * \mathrm{OpCycle}+\beta_{8} * \mathrm{BD}+\beta_{9} * \mathrm{NM}+\varepsilon+\varepsilon$

$\underline{\text { Variable }}$

Intercept

Ln(TotalAssets)

$\mathrm{BM}$

SGrowth

ROA

OCF

$\mathrm{DE}$

OpCycle

ACCC

$\mathrm{BD}$

NM
Model 10

$\underline{\text { Coefficient }} \underline{\text { T-statistic }} \underline{\text { p-value }}$

0.081

$-0.006$

$-0.002$

0.045

$-0.124$

0.000

0.000

0.004

0.018

$\begin{array}{rr}5.43 & <0.001 \\ -4.51 & <0.001 \\ -1.23 & 0.220 \\ 6.86 & <0.001 \\ -13.23 & <0.001 \\ 0.97 & 0.330 \\ 1.91 & 0.056 \\ 1.76 & 0.078 \\ 2.75 & 0.006\end{array}$

2.75

0.006

$\underline{\text { Coefficient }} \underline{\text { T-statistic }} \underline{\text { P-value }}$

\begin{tabular}{|c|c|c|}
\hline 0.077 & 5.19 & $<0.001$ \\
\hline-0.006 & -4.26 & $<0.001$ \\
\hline-0.002 & -1.20 & 0.230 \\
\hline 0.044 & 6.71 & $<0.001$ \\
\hline-0.124 & -13.23 & $<0.001$ \\
\hline 0.000 & 1.01 & 0.314 \\
\hline 0.000 & 1.93 & 0.054 \\
\hline 0.004 & 1.84 & 0.066 \\
\hline 0.008 & 0.97 & 0.334 \\
\hline 0.030 & 3.24 & 0.001 \\
\hline
\end{tabular}

Adjusted $\mathrm{R}^{2}=0.095$

Note: P-values are tailed. Variables are defined in Table 10. 


\section{LIST OF REFERENCES}

Abbott, L. J., Y. Park, and S. Parker. 2000. The effects of audit committee activity and independence on corporate fraud. Managerial Finance 26: 55-67.

Abbott, L., S. Parker, G. F. Peters, and K. Raghunandan. 2003a. The Association between Audit Committee Characteristics and Audit Fees. Auditing: A Journal of Practice \& Theory 22 (2): 17-32.

Abbot, L.J., S. Parker, G.F. Peters, and K. Raghunandan. 2003b. An empirical investigation of audit fees, nonaudit fees, and audit committees. Contemporary Accounting Research (Summer): 215-234.

Abbott, L.J., S. Parker, and G. F. Peters, G.F. 2006. Earnings management, litigation risk, and asymmetric audit fee responses. Auditing: A Journal of Practice and Theory 25 (1): $85-98$.

Abbott, L. J.; S. Parker, and G. F. Peters, G. F. 2010. Serving Two Masters: The Association between Audit Committee Internal Audit Oversight and Internal Audit Activities, Accounting Horizons 24(1): 1-24.

Abbott, L. J., S. Parker, G.F. Peters. 2004. Audit committee characteristics and restatements. Auditing: A Journal of Practice \& Theory 23: 69-87.

Agrawal, A., S. Chadha, 2005. Corporate governance and accounting scandals. Journal of Law and Economics 48 (2): 371-406.

Alford A., Jones J., R. Leftwich, and M. Zmijewski. 1993. The relative informativeness of accounting disclosures in different countries. Journal of Accounting Research 31 (Suppl.): 183-223.

Anderson, K. L. and T. L. Yohn. 2002. The Effect of 10-K Restatements on Firm Value, Information Asymmetries, and Investors' Reliance on Earnings. Working Paper, Georgetown University.

Archambeault, D and F.T. DeZoort. 2001. Auditor opinion shopping and the audit committee: An Analysis of suspicious auditor switches. International Journal of Auditing (5): $33-52$.

Aston R. H., J. J. Willingham, R. K. Elliott. 1987. An Empirical Analysis of Audit Delay. Journal of Accounting Research 25 (2): 275-292.

Aston R. H., P. R. Graul, J. D. Newton. 1989. Audit delay and the timeliness of corporate reporting. Contemporary Accounting Research 5 (2): 657-673. 
Bamber, E.M., L.S. Bamber, and M.P. Schoderbek. 1993. Audit structure and other determinants of audit report lag: An empirical analysis. Auditing: A Journal of Practice and Theory 12 (1): 1-23.

Bartov, E., and D. Cohen. 2008. "Mechanisms to Meet/Beat Analyst Earnings Expectations in the Pre- and Post-Sarbanes-Oxley Eras," Working Paper, New York University.

Barua, A., D. Rama, and V. Sharma. 2010. Audit Committee Characteristics and Investment in Internal Auditing. Journal of Accounting and Public Policy 29: 501-513.

Beasley, M. S., J. V. Carcello, and D. R. Hermanson. 2000. Fraudulent financial reporting: 1987-1997, An analysis of U.S. public companies. New York: Committee of Sponsoring Organizations of the Treadway Commission (COSO).

Beasley, M., J. Carcello, D. Hermanson, and T. Neal. 2009. The audit committee oversight process. Contemporary Accounting Research 26 (1): 65-122.

Bédard, J., S. M. Chtourou, and L. Courteau. 2004. The effect of audit committee expertise, independence, and activity on aggressive earnings management. Auditing: A Journal of Practice \& Theory 23 (2): 13-35.

Bedard, J.C. and K. Johnstone. 2004. Earnings manipulation risk, corporate governance risk, and auditors' planning and pricing decisions. The Accounting Review 79 (2): 277304.

Bell, T. B., W. R. Landsman, and D. A. Shackelford. 2001. Auditors' Perceived Business Risk and Audit Fees: Analysis and Evidence. Journal of Accounting Research 39 (1): 35 43.

Blue Ribbon Committee (BRC). 1999. Audit committee characteristics and restatements: A study of the efficacy of certain blue ribbon committee recommendations. New York, NY: New York Stock Exchange and National Association of Securities Dealers.

Bryan-Low, C. 2002. "Defining moment for SEC: Who's a financial expert?" Wall Street Journal (December 9): C1.

Carcello, J., D. Hermanson, T. Neal, and R. Riley. 2002. Board Characteristics and Audit Fees. Contemporary Accounting Research 19 (3): 365-384.

Carcello, J. V., D. R. Hermanson, and Z. Ye. 2011. Corporate Governance Research in Accounting and Auditing: Insights to Date and Directions for Future Research. Auditing: A Journal of Practice \& Theory 30 (August): 1-31. 
Carcello, J.V., C. Hollingsworth, A. Klein, and T. Neal. 2006. Audit Committee Financial Expertise, Competing Corporate Governance Mechanisms, and Earnings Management. Working Paper (February),

Carcello, J.V., C. Hollingsworth, A. Klein, and T. Neal. 2008. Audit Committee Financial Expertise, Competing Corporate Governance Mechanisms, and Earnings Management. Working Paper. University of Tennessee.

Carcello, J., and T.L. Neal. 2000. Audit committee composition and auditor reporting. The Accounting Review (October): 453-468.

Carcello and Neal. 2003. Audit committee characteristics and auditor dismissal following "new" going-concern reports. The Accounting Review (January): 95-117.

Carcello, J. V., T. L. Neal, Z. V. Palmrose, and S. Scholz. 2011. CEO involvement in selecting board members, audit committee effectiveness, and restatements. Contemporary Accounting Research 28 (2): 396-430.

Chambers, A. and S. Penman. 1984. Timeliness of Reporting and the Stock Price Reaction to Earnings Announcements. Journal of Accounting Research 22 (1): 21-47.

Charles, S. L., S. M. Glover, and N. Y. Sharp. 2010. The Association between Financial Reporting Risk and Audit Fees before and after the Historic Events Surrounding SOX. Auditing: A Journal of Practice and Theory 29: 15-39.

Cohen, J., G. Krishnamoorthy, and A. Wright. 2002. Corporate governance and the audit process. Contemporary Accounting Research (Winter): 573-594.

Cohen, J., L. M. Gaynor, G. Krishnamoorthy, and A. M. Wright. 2007. Auditor communications with the audit committee and the board of directors: Policy recommendations and opportunities for future research. Accounting Horizons 21 (2): 165-187.

Cohen, J., Krishnamoorthy, G., Wright, A., 2010. Corporate governance in the postSarbanesOxley Era: auditors' experiences. Contemporary Accounting Research 27 (3): 751-786.

Cohen, J. R., Hoitash, U., Krishnamoorthy, G., \& Wright, A. M. 2013. The effect of audit committee industry expertise on monitoring the financial reporting process. The Accounting Review 89(1): 243-273.

Craswell, A. T., J. R. Francis, and S. L. Taylor. 1995. Auditor brand name reputations and industry specializations. Journal of Accounting and Economics 20(3), 297-322. 
Davidson III, W.N., B. Xie, W. Xu. 2004. Market reaction to voluntary announcements of audit committee appointments: The effect of financial expertise. Journal of Accounting and Public Policy 23: 279-293.

De Angelo, L. E. 1981. Auditor Size and Audit Quality. Journal of Accounting and Economics (3): 183-199.

Dechow, P, R. Sloan and A. Sweeney. 1996. Causes and Consequences of Earnings Manipulations: An Analysis of Firms Subject to Enforcement Actions by the SEC. Contemporary Accounting Research 13 (1): 1-36.

DeFond M.L., R.N. Hann, X. Hu. 2005. Does the market value financial expertise on audit committees of boards of directors? Journal of Accounting Research (43) 2: 153193.

DeFond M. L., T. J. Wong, S. H. Li. 2000. The Impact of Improved Auditor Independence on Auditor Market Concentration in China. Journal of Accounting and Economics 28: 269 - 305 .

DeZoort, F. T. 1997. An investigation of audit committees' oversight responsibilities. Abacus (September): 208-227.

DeZoort, F.T. and S. E. Salterio. 2001. The effects of corporate governance experience and financial reporting and audit knowledge on audit committee members' judgments. Auditing, 20 (2): 31-49.

DeZoort, F. T., D.R. Hermanson, and R.W. Houston. 2003. Audit committee member support for proposed audit adjustments: A source credibility perspective. Auditing: A Journal of Practice and Theory (September): 189-205.

DeZoort, F.T., D. Hermanson, and R. Houston. 2008. Audit committee member support for

proposed audit adjustments: Pre-SOX versus post-SOX judgments. Auditing: A Journal of Practice \& Theory 27 (1): 85-104.

Dhaliwal, D., S. Eheitzman, O. Z. Li. 2006. Taxes, leverage, and the cost of equity capital. Journal of Accounting Research 44: 691-723.

Dhaliwal, D., V. Naiker, F. Navissi. 2010. The Association Between Accruals Quality and the Characteristics of Accounting Experts and Mix of Expertise on Audit Committees. Contemporary Accounting Research 27: 787-827.

Donaldson, W. H. 2003. Testimony concerning implementation of the Sarbanes-Oxley Act of 2002. Presented before the Senate Committee on Banking, Housing and Urban Affairs. 
Easton, P. D. and M. E. Zmijewski. 1993. SEC Form 10K/10Q Reports and Annual Reports to Shareholders: Reporting Lags and Squared Market Model Prediction Errors. Journal of Accounting Research 31 (1): 113-129.

Ettredge, M., C. Li and L. Sun. 2006. The impact of SOX Section 404 internal control quality assessment on audit delay in the SOX era. Auditing, A Journal of Practice \& Theory 25 (3): 1-23.

Feldmann, D. A., W. J. Read, and M. J. Abdolmohammadi. 2009. Financial restatements, audit fees, and the moderating effect of CFO turnover. Auditing: A Journal of Practice \& Theory 28(1): 205-223.

Ferguson, A., J.R. Francis and D.J. Stokes. 2003. The effects of firm-wide and officelevel industry expertise on audit pricing. The Accounting Review 78: 429-448.

Francis, J., R. Lafond, P. Olsson, and K. Schipper. 2005. The Market Pricing of Earnings Quality. Journal of Accounting and Economics 39: 295-327.

Francis, J. R., and D. Simon. 1987. A test of audit pricing in the small-client segment of the U.S. audit market. The Accounting Review 62 (January): 145-157.

Goh, B. W. 2009. Audit Committees, Boards of Directors, and Remediation of Material Weaknesses in Internal Control. Contemporary Accounting Research. 26(2): 549-579.

Gao, Y. 2011. The Sarbanes-Oxley Act and the Choice of Bond Market by Foreign Firms. Journal of Accounting Research 49: 933-968.

Gendron, Y., Bédard J. 2006. On the construction of audit committee effectiveness. Accounting, Organizations and Society 31: 211-239.

General Accounting Office (GAO). 2002. Financial Statement Restatements: Report to the Chairman, Committee on Banking, Housing, and Urban Affairs, U.S. Senate (October 2002). United States General Accounting Office. GAO-03-138. Washington, DC: GAO.

Goodwin-Stewart, J., and P. Kent. 2006. Relation between external audit fees, audit committee characteristics and internal audit. Accounting and Finance 46 (3): 387-404.

Hakansson, N. H. 1977. Interim Disclosure and Public Forecasts: An Economic Analysis and a Framework for Choice. The Accounting Review 52: 396-416.

Handerson, B.C. and S. E. Kaplan. 2000. An Examination of Audit Report Lag for Banks: A Panel Data Approach. Accounting, Auditing and Accountability Journal 19 (2): 159- 174. 
Hay, D. C., W. R. Knechel, and N. Wong. 2006. Audit Fees: A Meta-analysis of the Effect of Supply and Demand Attributes. Contemporary Accounting Research 23: 141191.

Hoitash, R., U. Hoitash, and J. C. Bedard. 2008. Internal control quality and audit pricing under the Sarbanes-Oxley Act. Auditing: A Journal of Practice and Theory (May): 105126.

Kinney, W. R., and L. S. McDaniel. 1993. Audit delay for firms correcting quarterly earnings. Auditing: A Journal of Practice \& Theory 12(2): 135-142.

Klein, A. 2002. Economic Determinants of Audit Committee Independence. The Accounting Review 77 (2): 435-452.

Knechel, W. R., and J. L. Payne. 2001. Additional evidence on audit report lag. Auditing 20(1): 137-146.

Krishnamoorthy, G., A. Wright and J. Cohen. 2002. Audit committee effectiveness and financial reporting quality: Implications for auditor independence. Australian Accounting Review (November): 3-13.

Krishnan, J. 2005. Audit committee financial expertise and internal control: An empirical analysis. The Accounting Review 80 (2): 649-675.

Krishnan, J, and J. Lee. 2009. Audit Committee Financial Expertise, Litigation Risk, and Corporate Governance. Auditing: A Journal of Practice \& Theory 28(1): 241- 261.

Krishnan, G. V., and G. Visvanathan. 2008. Does the SOX definition of an accounting expert matter? The association between audit committee directors ${ }^{\text {ee }}$ accounting expertise and accounting conservatism. Contemporary Accounting Research 25 (3): pp. 827-57.

Krishnan, J., and J. Yang. 2009. Recent trends in audit report and earnings announcement lags. Accounting Horizons 23 (3): 265-288.

McMullen, D.A., and K. Raghunandan. 1996. Enhancing audit committee effectiveness. Journal of Accountancy 182: 79-81

Munsif, V., K. Raghunandan, D. Rama, and M. Singhvi. 2011. Audit fees after remediation of internal control weaknesses. Accounting Horizons 25 (1): 87-105.

Naiker, V and D. S. Sharma. 2009. Former Audit Partners on the Audit Committee and Internal Control Deficiencies. The Accounting Review. 84 (2): 559-587.

Newton, J. D., and R. H. Ashton. 1989. The association between audit technology and audit delay. Auditing: A Journal of Practice \& Theory 8(Supplement): 22-37. 
Owens-Jackson Lisa A, Diana Robinson, Sandra Waller Shelton. 2009. The Association Between Audit Committee Characteristics, the Contracting Process and Fraudulent Financial Reporting. American Journal of Business 24 (1): 57-65.

Pincus, K., M. Rusbarsky, J. Wong. 1989. Voluntary formation of corporate audit committees among NASDAQ firms. Journal of Accounting and Public Policy 8: 239-265.

Public Company Accounting Oversight Board (PCAOB). 2010. Auditing Standard No. 8 - Audit Risk. Washington, DC: PCAOB.

Raghunandan, K., and D. Rama. 2006. SOX Section 404 material weakness disclosures and audit fees. Auditing: A Journal of Practice and Theory (May): 99-114.

Sarbanes-Oxley Act (SOX). 2002. Public Law No. 107-204. Washington, DC: GPO.

Raghunandan, K. and D. Rama. 2007. Determinants of audit committee diligence. Accounting Horizons. 21.3 (September): 265-280.

Scarbrough, D. P., D. Rama, and K. Raghunandan. 1998. Audit committee composition and interaction with internal auditing: Canadian evidence. Accounting Horizons, 12(1): $51-62$.

Sharma, V.D., and E. R. Iselin. 2012. The association between audit committee multipledirectorships, tenure, and financial misstatements. Auditing: A Journal of Practice and Theory 31 (3): 149-175.

Simon, D. T., and J. R. Francis. 1988. The effects of auditor change on audit fees: Tests of price cutting and price recovery. The Accounting Review 63: 255-269.

Schwartz, K. B., and B. S. Soo. 1996. The association between auditor changes and reporting lags. Contemporary Accounting Research 13 (1): 357-370.

Securities and Exchange Commission (SEC). 1999a. Proposed rule. Audit committee disclosure. Release No. 34-41987; File No. S7-22-99. Washington, DC: SEC.

. 1999b. Final rule: Audit committee disclosure. Release No. 34-42266; File No. S7-22-99. Washington, DC: SEC.

. 2000. Final rule: Revision of the Commission's Auditor Independence

Requirements. Release No. 3-7919; 34-43602; 35-27279; IC - 24744; IA 1911; FR-56; File No. S7-13-00. Washington, DC: SEC.

2002. Proposed rule: Additional form 8-K disclosure requirements and acceleration of filing date. Release No. 33-8106; 34-46084; File No. S7-22- 02. Washington, DC: SEC 
. 2002a. Proposed rule: Disclosure required by Sections 404, 406 and 407 of

the Sarbanes-Oxley Act of 2002. Release No. 33-8138; 34-46701; IC - 25575; File No. S7-40-02. Washington, DC: SEC.

2003a. Final rule: Standards relating to listed company audit committees.

Release No. 33-8220; 34-47654; IC - 26001; File No. S7-02-03. Washington, DC: SEC

2005. Revisions to Accelerated Filers Definition and Accelerated Deadlines for

Filing Periodic Reports. Release Nos. 33-8644; 34-52989; File No. S7-08-05.

Washington, DC: SEC.

Simon, D. T., and J. R. Francis. 1988. The effects of auditor change on audit fees: Tests of price cutting and price recovery. The Accounting Review 63: 255-269.

Simunic, D. A. 1980. The pricing of audit services: Theory and evidence. Journal of Accounting Research: 161-190.

Tanyi, P., K. Raghunandan, and A. Barua. 2010. Audit report lags after voluntary and Involuntary Auditor Changes. Accounting Horizons 24(4): 671-688.

Vafeas, N. 2003. Length of Board Tenure and Outside Director Independence. Journal of Business Finance and Accounting 30 (7-8):1043-1064.

Venkataraman, R., J. P. Weber, and M. Willenborg. 2008. Litigation Risk, Audit Quality, and Audit Fees: Evidence from Initial Public Offerings. Accounting Review 83: $1315-$ 1345.

Vicknair, D., Hickman, K., Carnes. K.C. 1993. A note on audit committee independence: Evidence from the NYSE on "Grey" area directors. Accounting Horizons (7) 1: 53-57.

Whisenant, S., S. Sankaraguruswamy, and K. Raghunandan. 2003. Evidence on the joint determination of audit and non-audit fees. Journal of Accounting Research 41 (4): 721744.

Williams, D.D. and M. W. Dirsmith. 1988. The Effects of Audit Technology on Auditor Efficiency: Auditing and the Timeliness of Client Earnings Announcements. Accounting, Organizations and Society: 487-508.

Williams, S.P. (2005). Meet the experts. Accounting Horizons, 19(4), 255-265.

Yang, J. S. and J. Krishnan. 2005. Audit Committees and Quarterly Earnings Management. International Journal of Auditing, 9, 201-219. 
Xie, B., W. Davidson, and P. DaDalt. 2003. Earnings management and corporate governance: The role of the board and the audit committee. Journal of Corporate Finance 9 (3): 295-316.

Zhang Y, J. Zhou J, and N. Zhou N. 2007. Audit committee quality, auditor independence and internal control weaknesses. Journal of Accounting and Public Policy 26: $300-327$.

Zmijewski, M. 1984. Methodological issues relating to the estimation of financial distress prediction models. Journal of Accounting Research 22 (Supplement): 59-82. 
VITA

\section{IZHAR HAQ}

July 17, 1963

Born, Karachi, Pakistan

Bachelor of Science, Computer Engineering

University of Miami

Miami, Florida

Master of Accounting

Nova Southeastern University

Fort Lauderdale, Florida

Master of Business Administration

Indiana University

Bloomington, Indiana

$1995-1998$

$1998-2000$

Controller, Sony Discos

Sony Music International

Miami Beach, Florida

$2000-2005$

Chief Financial Officer, BMG US Latin

Bertelsmann AG

Coral Gables, Florida

2005 - Present

Senior Associate Controller

Florida International University

Miami, Florida

Presidential Excellence Award, 2010

$2006-2015$

Doctorate Candidate

Florida International University

Miami, Florida 